\title{
15
}

\section{Development of marine and terrestrial resource use in the Talaud Islands AD 1000-1800, northern Sulawesi region}

\author{
Rintaro 0no, Sriwigati and Joko Siswanto
}

\begin{abstract}
This chapter reviews the excavation results from the Leang Buida and Bukit Tiwing sites in the Talaud Islands of North Sulawesi, with a focus on the faunal remains and likely fishing tools. The available Carbon-14 determinations date the occupation of Leang Buida on Kabaruan Island to around AD 1000-1600 and Bukit Tiwing on Salibabu Island to around AD 1500-1800. From comparing the excavation results to data from other sites in Southeast Asia, East Asia and the Pacific, we outline the possible development of marine and terrestrial use of the remote Talaud Islands during the Metal Age and historic times.
\end{abstract}

Keywords: marine exploitation, fishing technology, animal use, Talaud Islands

\section{Introduction}

This chapter deals with the excavated remains from two sites in the remote Talaud Islands of North Sulawesi in the context of the development of inter-island maritime networks in Island Southeast Asia (ISEA) during the Metal Age. The Metal Age refers to the time of availability of metal goods and tools, notably copper or bronze and iron, which in ISEA evidently appeared together in the last centuries BC, along with a range of exotic imports (Bellwood 2017). Characteristic pottery (e.g. Solheim 2006; Ono et al. 2013; Yamagata et al. 2013), precious and rare materials such as metal, glass and nephrite (e.g. Francis 2002; Bellina 2003; Bulbeck 2010; Dussubieux and Gratuze 2010; Hung and Bellwood 2010; Hung et al. 2013), and trade ceramics can be some of the best archaeological indicators for the establishment of ISEA inter-island maritime network systems. Other potential archaeological indicators include the appearance of plant and terrestrial animal resources in remote islands where no such resources naturally existed before their evident introduction by humans. Also, the appearance of new fishing tools associated with the development of fishing technology and marine exploitation can be another indicator.

Based on these understandings, we conducted archaeological excavations of sites dating to around AD 1000 to 1800 in the Sangihe-Talaud Islands, Eastern Indonesia, during 2003 to 2005. In this chapter, we introduce the excavated fish and other animal remains along with possible capture tools in the Talaud Islands as a platform for discussing the possible development of inter-island maritime networks and the associated marine and terrestrial resource use. 


\section{Talaud Islands and associated archaeological sites}

The Talaud Islands form part of the small island group of the Sangihe and Talaud chain, geopolitically located in Indonesia (Figure 15.1), between the northern Sulawesi mainland and Mindanao in the Philippines. The Sangihe Islands extend north from Minahasa (North Sulawesi) for about $230 \mathrm{~km}$, and include the two main islands of Siau and Sangir. The Talaud Islands are located about $120 \mathrm{~km}$ northeast of the Sangihe group. The Talaud group is basically composed of three large islands (see Figure 15.2), including Karakelang $\left(976 \mathrm{~km}^{2}\right.$ ), Salibabu (about $95 \mathrm{~km}^{2}$ ) and Kabaruan (about $200 \mathrm{~km}^{2}$ ), along with eight small (about $10-18 \mathrm{~km}^{2}$ each) uplifted coral islands in the north called the Nanusa Islands. The Talaud Islands have no active volcanos and are low-lying (the highest point being the summit of Mount Manuk in Karakelang at 648 metres above sea level (m asl)).

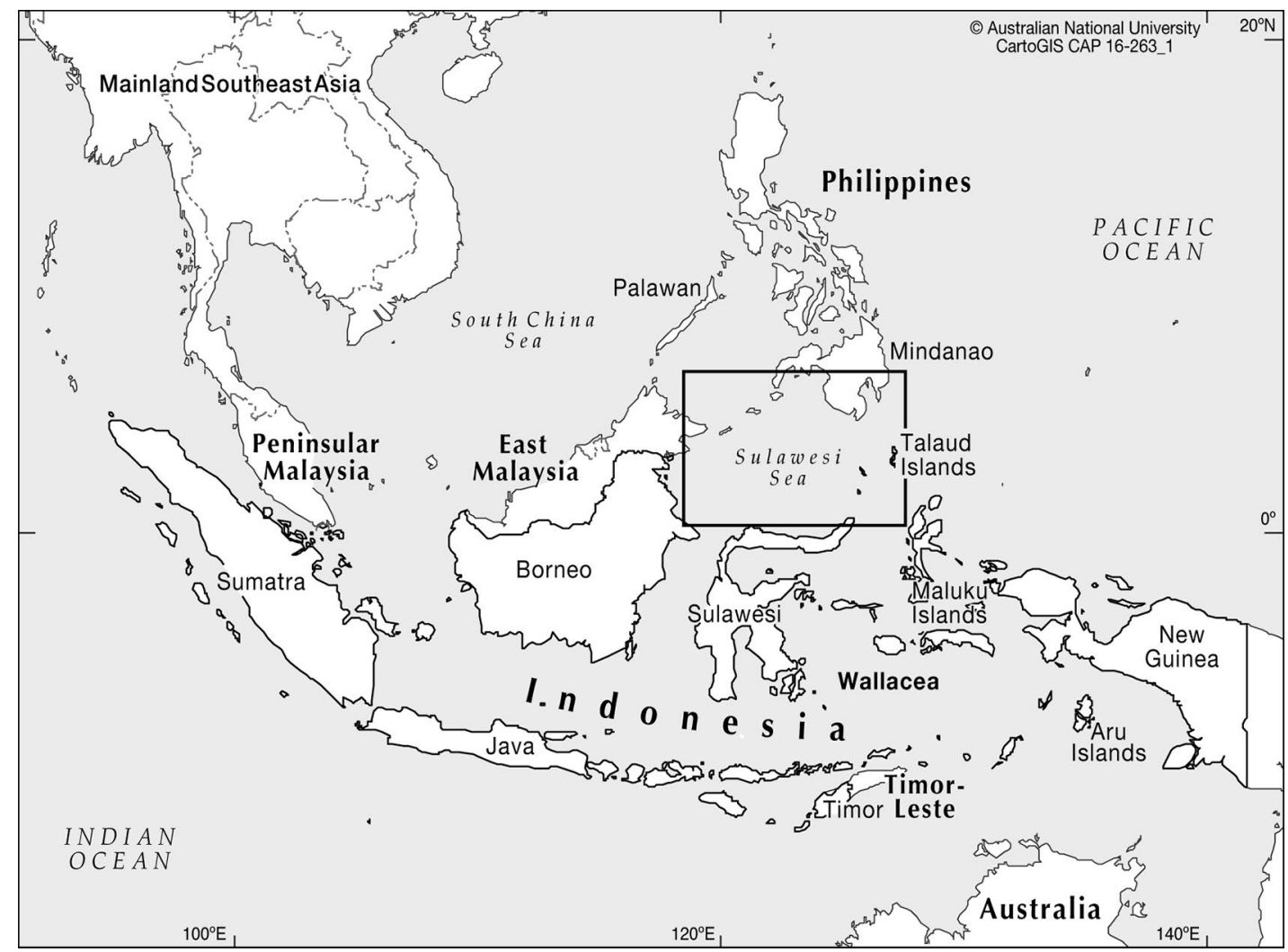

Figure 15.1: Location of Sulawesi Sea and Talaud Islands.

Source: Jennifer Sheehan, CartoGIS, College of Asia and the Pacific, The Australian National University; based on original by Rintaro 0 no. 


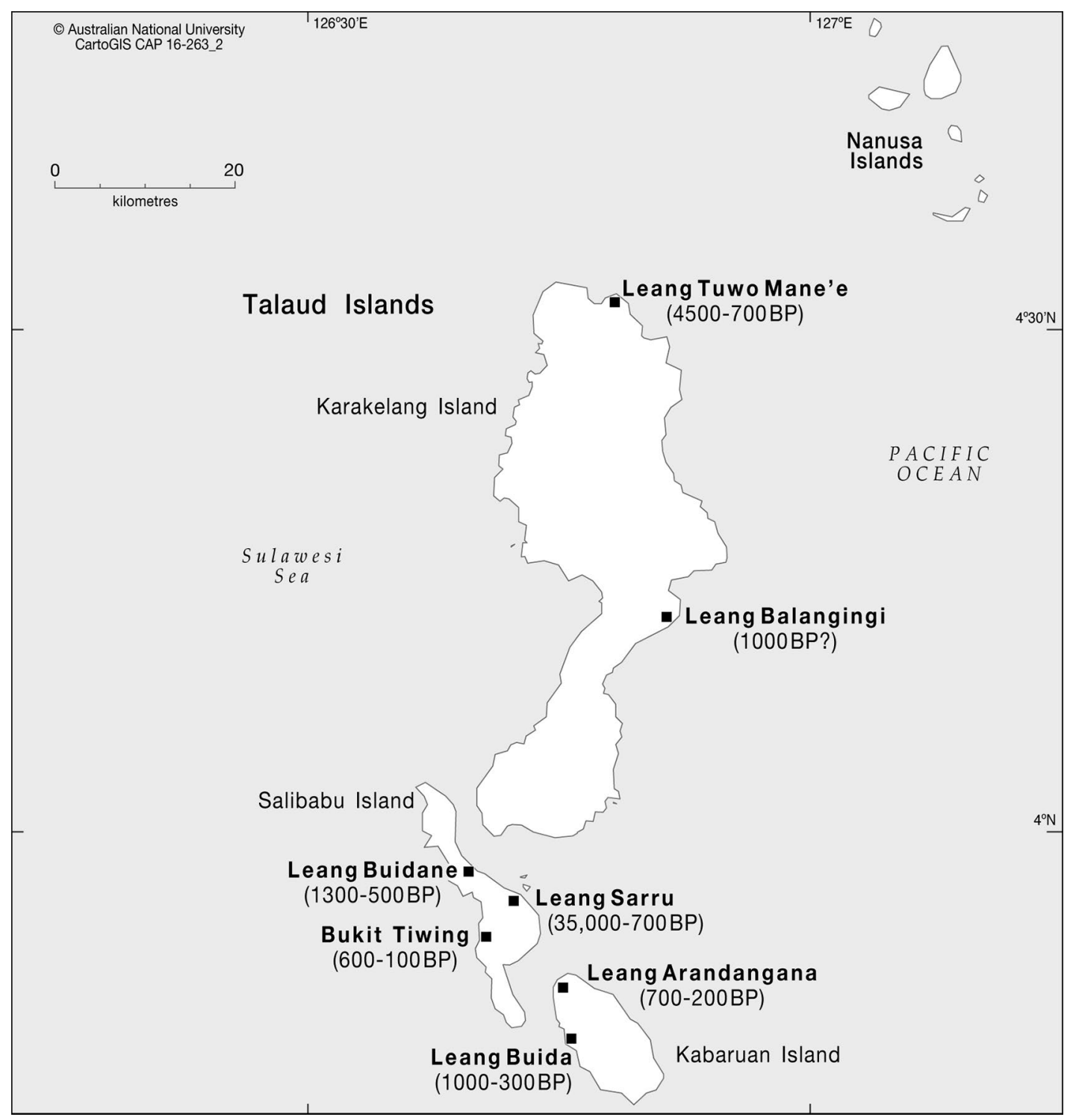

Figure 15.2: Location of archaeological sites in the Talaud Islands.

Source: Jennifer Sheehan, CartogIS, College of Asia and the Pacific, The Australian National University; based on original by Rintaro 0no.

The isolated location of the Talaud Islands, more than $100 \mathrm{~km}$ from any adjacent islands, was also the case during Pleistocene times, even though the Talauds boast the oldest archaeological site in the Sulawesi Sea-Leang Sarru (see Figure 15.2). The original excavation of Leang Sarru by Tanudirjo $(2001,2005)$ and our re-excavation (Ono and Soegondho 2004; Ono et al. 2009, 2015) found a large number of flaked stone artefacts, mainly chert, along with a variety of marine and land shell remains dating to between 35,000 years ago and the early Holocene (around 8000 years ago). However, there are no known archaeological sites dating to between c. 8000 and 5500 years ago, and so it is unclear whether the early inhabitants who migrated to the Talaud Islands during the Late Pleistocene continually inhabited these islands or not.

The next oldest traces of human habitation in the Talaud Islands derive from the Leang Tuwo Mane'e site located at the northern tip of Karakelang Island (see Figure 15.2). The original excavation by Bellwood (1976) and the re-excavation by Tanudirjo (2001) found a Neolithic layer with pottery including red-slipped sherds dating back to around $1500 \mathrm{BC}$, and an older layer 
with some flaked stone but no pottery dating back to around 5500 years ago. It is unclear whether the pre-pottery layer represents habitation by descendants of the Leang Sarru occupants or other immigrants to the Talauds. However, Leang Tuwo Mane'e had possibly been used continually from Neolithic to recent times at around $\mathrm{AD} 1700,{ }^{1}$ considering also the current village located next to the site, including a 'Late Phase' with Chinese trade ceramics and Rarangunusa-style pottery, which Bellwood (1976) dates to the 2nd millennium AD.

All other archaeological sites in the Talauds are post-Neolithic and date entirely to the centuries AD. Among them, Leang Buidane on Salibabu Island is a secondary burial cave site with a large number of human bones, burial jars, bronze and iron fragments, and accessories including glass, shell and various carnelian and other stone beads. Based on a thermoluminescence date from an excavated baked clay mould of around $\mathrm{AD} 1000$ and a radiocarbon date of $510 \pm 80 \mathrm{BP}$ (ANU 1516) on charcoal excavated from the top layer above the jar burials, Bellwood (1976:278) estimated the date of the burials to between AD 700 and 1200. Leang Arandangana on Kabaruan Island is another Metal Age site, and its lower layer is dated to around AD 1200 from marine shell samples. The site also yielded a number of Rarangunusa-style potsherds from its two layers and two pieces of Chinese trade ceramics from the upper layer (Tanudirjo 2001).

Leang Buida on Kabaruan Island, one of the sites we report on here, is dated to around AD 1000 in its lower layers, making these layers contemporary with the Leang Buidane burials, even though Leang Buida is mainly a habitation site. The upper layers of the site date to around $\mathrm{AD}$ 1600, while another site on Salibabu Island, Bukit Tiwing, dates to around AD 1500-1800. Both sites produced large numbers of potsherds, possible fishing gear and other tools, along with a large quantity of marine and terrestrial faunal remains. The earthenware pottery and its motifs from these two sites seem to have similarities with their Leang Buidane counterparts, while Leang Buida also has a number of Rarangunusa-style potsherds, mainly from the upper layers but also from the bottom layer.

The Rarangunusa style has a widespread distribution, especially within the southern Philippines, including Mindanao, Davao, Cotabato and Samar (Spoehr 1973; Solheim et al. 1979) and in Eastern Indonesia including Haruku Island in Northern Maluku (Soegondho 1996) and the Sangihe-Talaud Islands (see Bellwood 1976, 1980; Tanudirjo 2001; Ono 2004; Ono et al. 2013). Bellwood (1976:282) suggests that the Rarangunusa decoration style might have originated in Mindanao and spread through intermarriage and the movement of potters (rather than by mass population movement) in early historic times, mainly under European or Islamic influence.

Based on this background, we summarise the excavation results from Leang Buida and Bukit Tiwing, and discuss the possible development of their marine and terrestrial resource use and also inter-island networks during AD 1000-1800.

\section{Excavation of Leang Buida}

Leang Buida site is a limestone cave (leang) site along the western coast of Kabaruan Island (Figure 15.2). The cave mouth is about $8 \mathrm{~m}$ in length and $4 \mathrm{~m}$ in height, and the length of the inner area expands to about $10 \mathrm{~m}$ to form a tight sheltered area (Figure 15.3A). Fragments of shells and potsherds were scattered on the surface. Most of these potsherds are plain with some Rarangunusa. The site was first excavated by the Manado Archaeology Office and Ono in 2005, and a further $10 \mathrm{~m}^{2}$ area was later excavated by the Manado Archaeology Office in 2007 and 2008.

1 There are three Carbon-14 dates from Layer 2, which is considered Early Metal to historic, and these are 990 \pm 100 BP (ANU 1715) on Turbo shell from the lower part of Layer 2, and $410 \pm 60 \mathrm{BP}$ (ANU 1514) and 250 70 BP (ANU 1513) on charcoal from the upper part of Layer 2 (Bellwood 1976:261). 

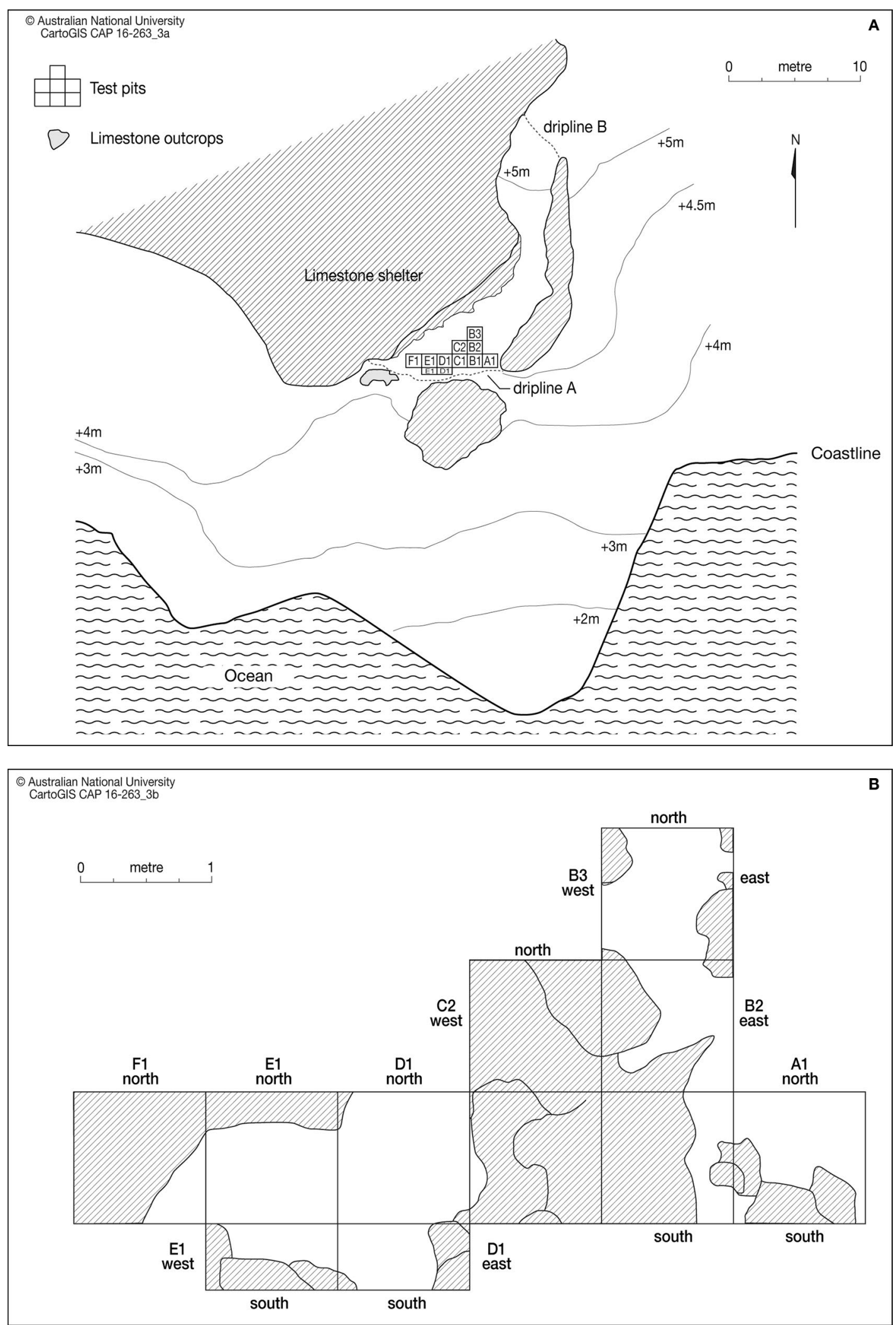

Figure 15.3: Leang Buida (A) and the excavated area in 2005 (B).

Note the contour breaks in $A$ at places where the rocky cliffs of the coastline drops precipitously into the sea. Source: Jennifer Sheehan, CartoGIS, College of Asia and the Pacific, The Australian National University; based on original by Manado Archaeology Office. 
We opened a $10 \mathrm{~m}^{2}$ excavated area around the mouth of the shelter in our 2005 excavation (Figure 15.3B) using spit depths of $10 \mathrm{~cm}$. During the excavation, we first used both $5 \mathrm{~mm}$ and $3 \mathrm{~mm}$ sized mesh for dry screening, but owing to the wetness of the excavated sediment, we gave up on trying to use the $3 \mathrm{~mm}$ sized mesh. Our excavation indicated three cultural layers down to 130 $\mathrm{cm}$ (at the maximum depth from the surface): Layer 1 as top soil; Layer 2 as a blackish organic soil containing lots of shells, potsherds and animal bones; and Layer 3 as a sticky yellowish soil containing a lower concentration of habitation debris.

All seven Accelerator Mass Spectrometry (AMS) dates available for the site are consistent in indicating a difference of about 600 years between Layer 3 and Layer 2 (Table 15.1). However, the AMS dates on marine shell are about 300 years older than the AMS dates on charcoal from the same layer, apparently reflecting marine reservoir effects, hence we here refer to the AMS dates from charcoal samples. Thus, in terms of cultural layers and AMS dates, Leang Buida registers two occupation phases respectively dated to around AD 1600 (Layer 2) and AD 1000 (Layer 3). It should be added, however, that there may also have been earlier habitation at the site, which has not been preserved due to scouring out of older deposit through exceptionally high tides, as can occur at coastal sites such as Leang Buida.

Table 15.1: AMS Dates from Leang Buida.

\begin{tabular}{|c|c|c|c|c|c|}
\hline Lab. Code & Sample & Layer & Depth & Date (BP) & Age (cal AD) ${ }^{(\mathrm{a})}$ \\
\hline TERRA-070407a06 & Turbo sp. & 3 & $\mathrm{E} 1 / 120 \mathrm{~cm}$ & $1358 \pm 31$ & - \\
\hline TERRA-070407a07 & Turbo sp. & 3 & $\mathrm{E} 1 / 70 \mathrm{~cm}$ & $1312 \pm 34$ & - \\
\hline TERRA-070407a08 & Turbo sp. & 2 & $\mathrm{E} 1 / 30 \mathrm{~cm}$ & $708 \pm 33$ & - \\
\hline TERRA-070407a17 & Charcoal & 3 & $\mathrm{~F} 1 / 100 \mathrm{~cm}$ & $998 \pm 32$ & 983-1152 \\
\hline TERRA-070407a18 & Charcoal & 3 & $\mathrm{D} 1 / 90 \mathrm{~cm}$ & $965 \pm 32$ & $1017-1155$ \\
\hline TERRA-070407a19 & Charcoal & 2 & $01 / 70 \mathrm{~cm}$ & $348 \pm 33$ & $1460-1636$ \\
\hline TERRA-070407a20 & Charcoal & 2 & $01 / 40 \mathrm{~cm}$ & $316 \pm 36$ & $1475-1648$ \\
\hline
\end{tabular}

(a) 95\% calibrated range from Intcal13 (Bronk Ramsey 2016).

Source: Rintaro 0no.

Our excavation unearthed thousands of shellfish $(\mathrm{n}=21,487)$, fish and animal remains with potsherds including both decorated $(n=409)$ and plain sherds $(n=8100)$, chert flakes $(n=297)$, stone adzes $(n=2)$, stone tools identified as nutcrackers $(n=37)$, and fragments of iron $(n=14)$ and two trade ceramic sherds (Table 15.2). As for macro-plant remains, Canarium nut shells $(\mathrm{n}=176)$ were excavated. Iron fragments were recovered only from Layer 1, while the two trade ceramic sherds (origin yet unknown) were excavated from Layer 3.

Table 15.2: Excavated cultural remains (counts) in each grid unit at Leang Buida in 2005.

\begin{tabular}{|l|r|r|r|r|r|r|r|r|r|r|r|}
\hline Unit & $\begin{array}{l}\text { Decorated } \\
\text { potsherds }\end{array}$ & $\begin{array}{c}\text { Plain } \\
\text { potsherds }\end{array}$ & $\begin{array}{c}\text { Imported } \\
\text { ceramic } \\
\text { sherds }\end{array}$ & $\begin{array}{c}\text { Stone } \\
\text { flakes }\end{array}$ & $\begin{array}{c}\text { Stone } \\
\text { adzes }\end{array}$ & $\begin{array}{c}\text { Nut } \\
\text { crackers }\end{array}$ & $\begin{array}{c}\text { Iron } \\
\text { tools }\end{array}$ & $\begin{array}{c}\text { Fishnet } \\
\text { sinkers }\end{array}$ & Shells & $\begin{array}{c}\text { Animal } \\
\text { bones }\end{array}$ & $\begin{array}{c}\text { Canarium } \\
\text { nuts }\end{array}$ \\
\hline A1 & 36 & 658 & 0 & 52 & 0 & 0 & 1 & 0 & 2441 & 119 & 5 \\
\hline B1 & 16 & 216 & 0 & 4 & 0 & 3 & 0 & 0 & 855 & 2 & 8 \\
\hline B2 & 16 & 200 & 0 & 28 & 0 & 0 & 0 & 0 & 1319 & 0 & 24 \\
\hline B3 & 8 & 145 & 0 & 4 & 0 & 0 & 0 & 0 & 1009 & 11 & 0 \\
\hline C1 & 19 & 240 & 0 & 15 & 0 & 1 & 0 & 0 & 1268 & 7 & 4 \\
\hline C2 & 6 & 147 & 0 & 8 & 0 & 0 & 0 & 0 & 411 & 0 & 6 \\
\hline D1N & 33 & 1431 & 1 & 55 & 0 & 3 & 2 & 2 & 3591 & 416 & 32 \\
\hline D1S & 30 & 541 & 1 & 8 & 1 & 4 & 0 & 0 & 1373 & 380 & 0 \\
\hline E1N & 91 & 1808 & 0 & 84 & 0 & 11 & 9 & 2 & 3927 & 599 & 54 \\
\hline
\end{tabular}




\begin{tabular}{|l|r|r|r|r|r|r|r|r|r|r|r|}
\hline Unit & $\begin{array}{l}\text { Decorated } \\
\text { potsherds }\end{array}$ & $\begin{array}{c}\text { Plain } \\
\text { potsherds }\end{array}$ & $\begin{array}{c}\text { Imported } \\
\text { ceramic } \\
\text { sherds }\end{array}$ & $\begin{array}{c}\text { Stone } \\
\text { flakes }\end{array}$ & $\begin{array}{c}\text { Stone } \\
\text { adzes }\end{array}$ & $\begin{array}{c}\text { Nut } \\
\text { crackers }\end{array}$ & $\begin{array}{c}\text { Iron } \\
\text { tools }\end{array}$ & $\begin{array}{c}\text { Fishnet } \\
\text { sinkers }\end{array}$ & Shells & $\begin{array}{c}\text { Animal } \\
\text { bones }\end{array}$ & $\begin{array}{c}\text { Canarium } \\
\text { nuts }\end{array}$ \\
\hline E1S & 46 & 1317 & 0 & 30 & 0 & 4 & 0 & 0 & 2720 & 512 & 7 \\
\hline F1 & 108 & 1397 & 0 & 9 & 1 & 11 & 2 & 1 & 2573 & 841 & 36 \\
\hline Total & 409 & 8100 & 2 & 297 & 2 & 37 & 14 & 5 & 21,487 & 2887 & 176 \\
\hline
\end{tabular}

Source: The authors.

Most of the decorated potsherds from Leang Buida can be classified with the Rarangunusa type. Rarangunusa pottery mainly comprises restricted vessels with everted rims, globular or carinated bodies and round bases (Tanudirjo 2001). Rims are generally rounded and tapering (Figure 15.4). Some rims have notched lips or are inflected outside the lip. The most distinctive characteristic of this pottery are the parallel incisions mostly made by two- or three-pronged tools, arranged in vertical zones (Figures $15.4 \mathrm{~A}$ and $15.4 \mathrm{C}$ ) on the outer wall of the vessel, generally from a carination or point of vertical tangency up to the lip. Among the popular motifs are paired vertical lines, vertical and horizontal zigzags, and paired notches lined in a vertical row. As described in the Introduction to this chapter, this pottery type has been dated to the 2nd millennium AD (Bellwood 1976; Tanudirjo 2001).

A
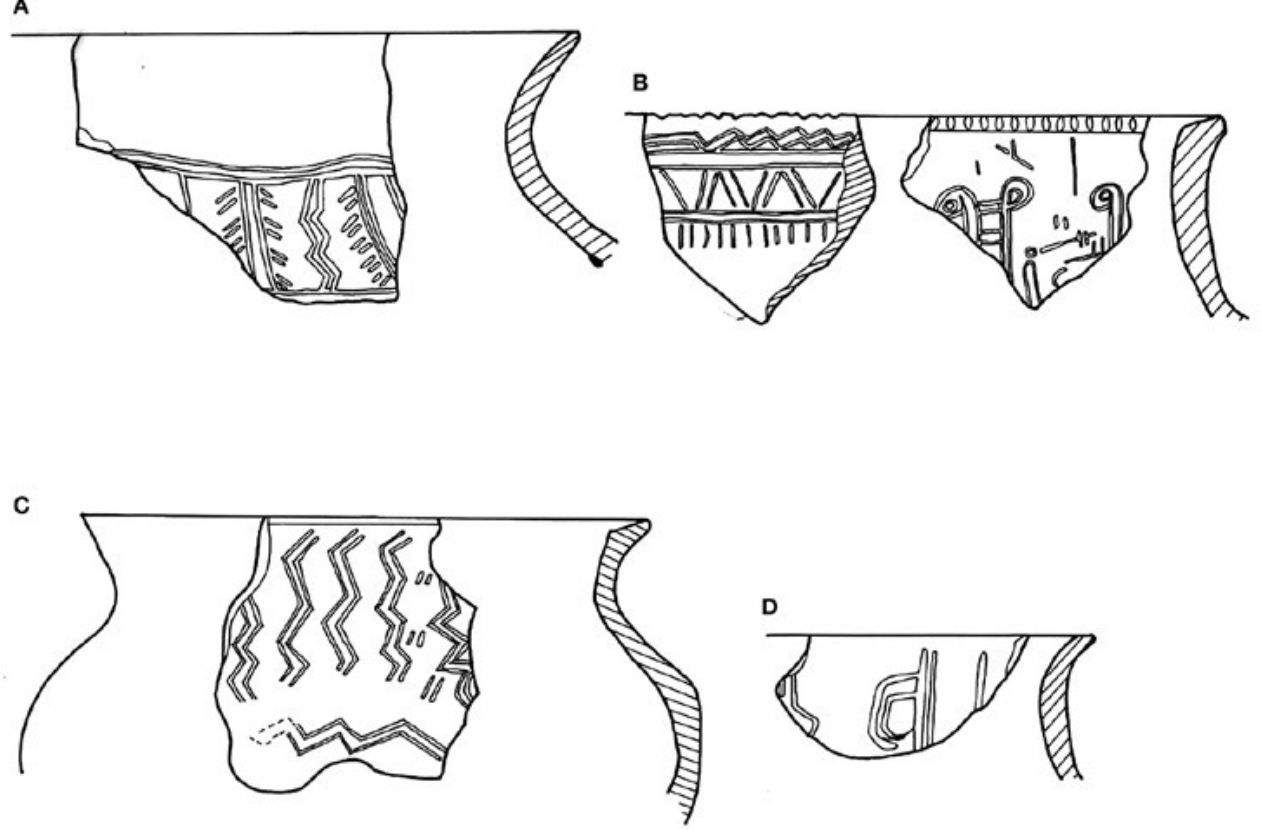

Figure 15.4: Decorated pottery from Leang Buida.

A: Decorated neck from square F1 Spit 11. B: Decorated rims from square F1 Spit 7. C: Decorated rim and shoulder from square F1 Spit 7. D: Decorated rim from square F1 Spit 7.

Source: Manado Archaeology Office.

However, our excavation at Leang Buida indicates that the Rarangunusa pottery prototype had already appeared by $\mathrm{AD} 1000$, possibly developed from Metal Age pottery styles and decorated motifs. For example, one of the decorated lip sherds from Layer 3 (Figure 15.4B) has a horizontal translation of paired zigzags on its inner lip, more simplified than the horizontal triangular mazes illustrated for Leang Buidane (Bellwood 1976:Figure 11) but different in orientation from the vertical translation of paired zigzags typical of Rarangunusa decorations (Bellwood 1976: Plate IIc). Considering also the excavation results at Liang Arandangana by Tanudirjo (2001), we may infer that the Rarangunusa motifs do not show any spatial patterning and persisted without radical 
changes for hundreds of years. Bellwood (1976) proposed that the Rarangunusa style might have survived until as recently as the mid-20th century. While not disagreeing with this proposal, we add the possibility that the designs may have become more simple and functional over time.

\section{Fishing tools from Leang Buida}

One class of special finds from Leang Buida involves variably sized clay tools with two punched holes, which are probably fishnet sinkers $(\mathrm{n}=5)$. They can be classified into two main types: the rounded type $(n=2$; Figure 15.5C, Figure 15.6B) and the disc-shaped type $(n=3$; Figures 15.5B and 15.5D; Figures 15.6C-E). Among these, the smallest disc-shaped sinker and the larger of the rounded sinkers were excavated from Layer 3 (respectively $130 \mathrm{~cm}$ and $110 \mathrm{~cm}$ in depth), while the others were from Layer $2(70 \mathrm{~cm}$ in depth). To judge from their excavated context, these clay sinkers appeared by AD 1000 and their use continued to at least AD 1600.

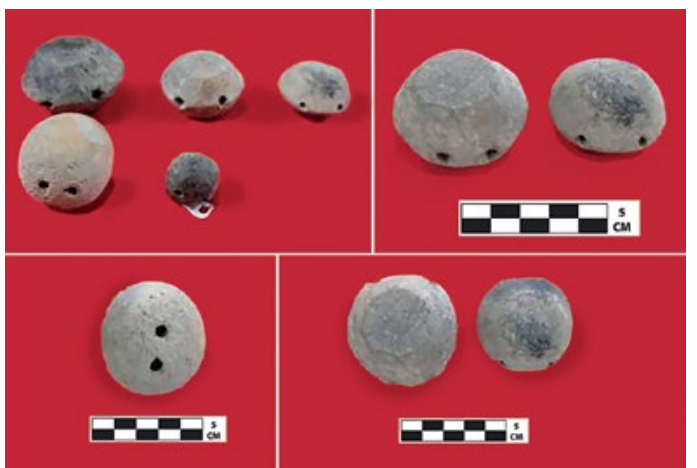

Figure 15.5: Photographs of clay net sinkers from Leang Buida.

Source: Rintaro 0no.

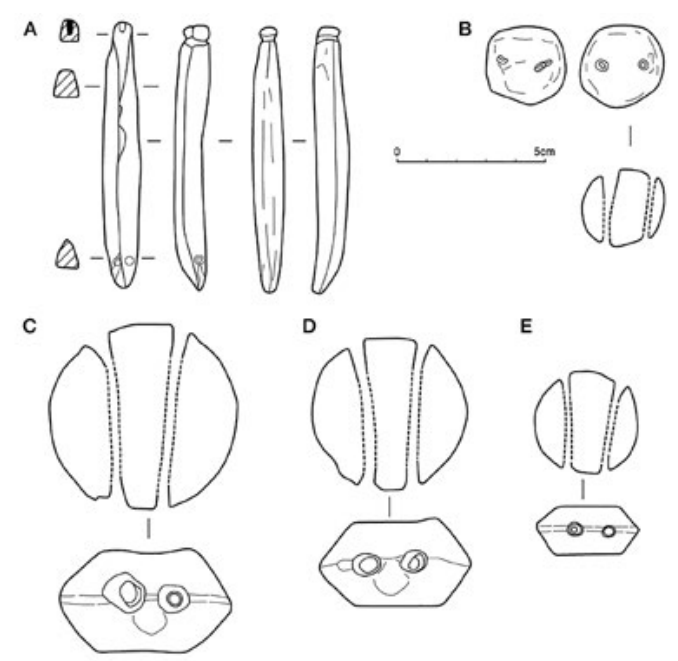

Figure 15.6: Illustrations of Leang Buida fishing tools.

A: Suspected lure shanks, B: rounded clay net sinker; C-E: disc-shaped clay net sinker.

Source: Jennifer Sheehan, CartoGIS, College of Asia and the Pacific, The Australian National University; based on sketches by Rintaro 0 no.
Net sinkers of clay or stone are common fishing tools in East Asia, including Japan, back to 8000 years ago. The older sinkers were mainly simple, for instance using fragments of potsherds or pebble stones, while the more sophisticated sinkers with a single furrow or double furrows appeared after the Middle to Late Jomon age dated to around 2-1000 years BC. After the Yayoi period around 500-0 BC, the tubular type of clay sinker with a single hole become common widely across East Asia as far south as Taiwan (e.g. Li 1997, 2002). However, so far no net sinkers have been found or excavated in ISEA, including Eastern Indonesia, and so our finding in Leang Buida may be the first archaeological evidence of clay net sinkers anywhere in Indonesia, including the Sulawesi region. Interestingly, all of the Leang Buida net sinkers have two holes in them. In East Asia, stick-shaped net sinker of various sizes with two holes appeared in Western Japan after around AD 400 and were commonly used until around AD 1200. These sinkers are not similar in shape to those from Leang Buida, but bolster the case for inferring that clay artefacts with two holes could be net sinkers. 
Another important finding related to fishing involves two possible lure shanks made from Tridacna shell (Figure 15.6A, Figure 15.7). Both were excavated from the middle to upper layers by the Manado Archaeology Office in 2007. Both lure shanks have a notch possibly for attaching a line at one end, while the other end is slightly bent upward and has a pierced hole. Interestingly, the surface pierced by the hole is broad and flat on one specimen but raised and bevelled on the other specimen. Since they were unearthed from Leang Buida's middle to upper layers, they would date to around AD 1600. However, no such artefacts have yet been found in ISEA, including Eastern Indonesia, hence they may be the first archaeological evidence for the use of shell lure shanks in the region.

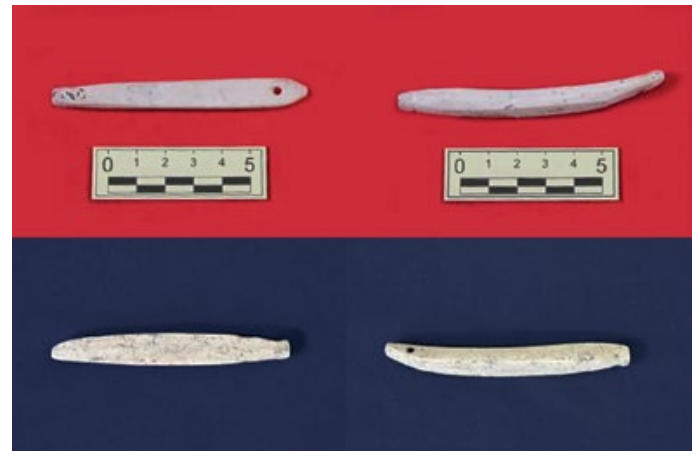

Figure 15.7: Suspected lure shanks made from Tridacna shell, with hole from front to back sides (top) and from right to left sides (bottom). Source: Rintaro Ono.

In southern Wallacea and Near Oceania, fish hooks made of Trochus date back to the Late Pleistocene in Alor (Samper Carro et al. 2016) and Timor (O'Connor et al. 2011). In Remote Oceania, a variety of one-piece rotating or trolling fish hooks made of Trochus and Turbo shell appeared on early Lapita sites in Melanesia dated to 1300-800 BC (e.g. Kirch 1997; Szabó 2010), while one-piece rotating fish hooks of Isognomon and rarely Turbo shell appeared with early human settlement in the Marianas Islands, Micronesia dated to $1500-1000 \mathrm{BC}$ (e.g. Hung et al. 2011). After around AD 100-
400, pearl-shell lure shanks become common in Melanesia and some islands in Micronesia, while compound or two-piece hooks and trolling shanks appeared mainly after AD 1000 in the Marianas.

However, there have been no discoveries of shell-made fish hooks and trolling gear in northern Wallacea including the SangiheTalaud Islands prior to our finding of an apparent trolling shank used in the Talaud Islands by $\mathrm{AD} 1600$. Interestingly, one of the Remote Oceanic islands closest to the Talauds, Tobi Island in the southwestern Palau group, has produced a number of Tridacna trolling shanks, and the earliest dates for prehistoric sites in Tobi now register to around $\mathrm{AD}$ 1700 (Intoh and Ono 2006:Figure 6). The Tobi Tridaca shanks are not exactly the same as the Talaud ones, but there are similarities between them, and cultural influence or human interaction between the Talauds and Tobi Islands would be plausible. However, it should also be noted that the only other suggestion of shared material culture between these islands involves Tridacna shell adzes (moreover, represented only as surface finds in the Talauds).

\section{Excavation of Bukit Tiwing}

Bukit Tiwing is an open site located on a hill (bukit) called 'Tiwing' about $1 \mathrm{~km}$ inland from the village of Ballang, on the western coast of Salibabu Island. The site is situated in secondary forest on the flat top of a small limestone hill surrounded by cliffs (Figure 15.8). The flat area covers about $15 \mathrm{~m}$ x $20 \mathrm{~m}$. Fragments of imported ceramics, probably from China are scattered on the surface. Local potsherds were also found quite abundantly and some of them are of the Rarangunusa type. The site was excavated by the Manado Archaeology Office and Ono in 2004. 


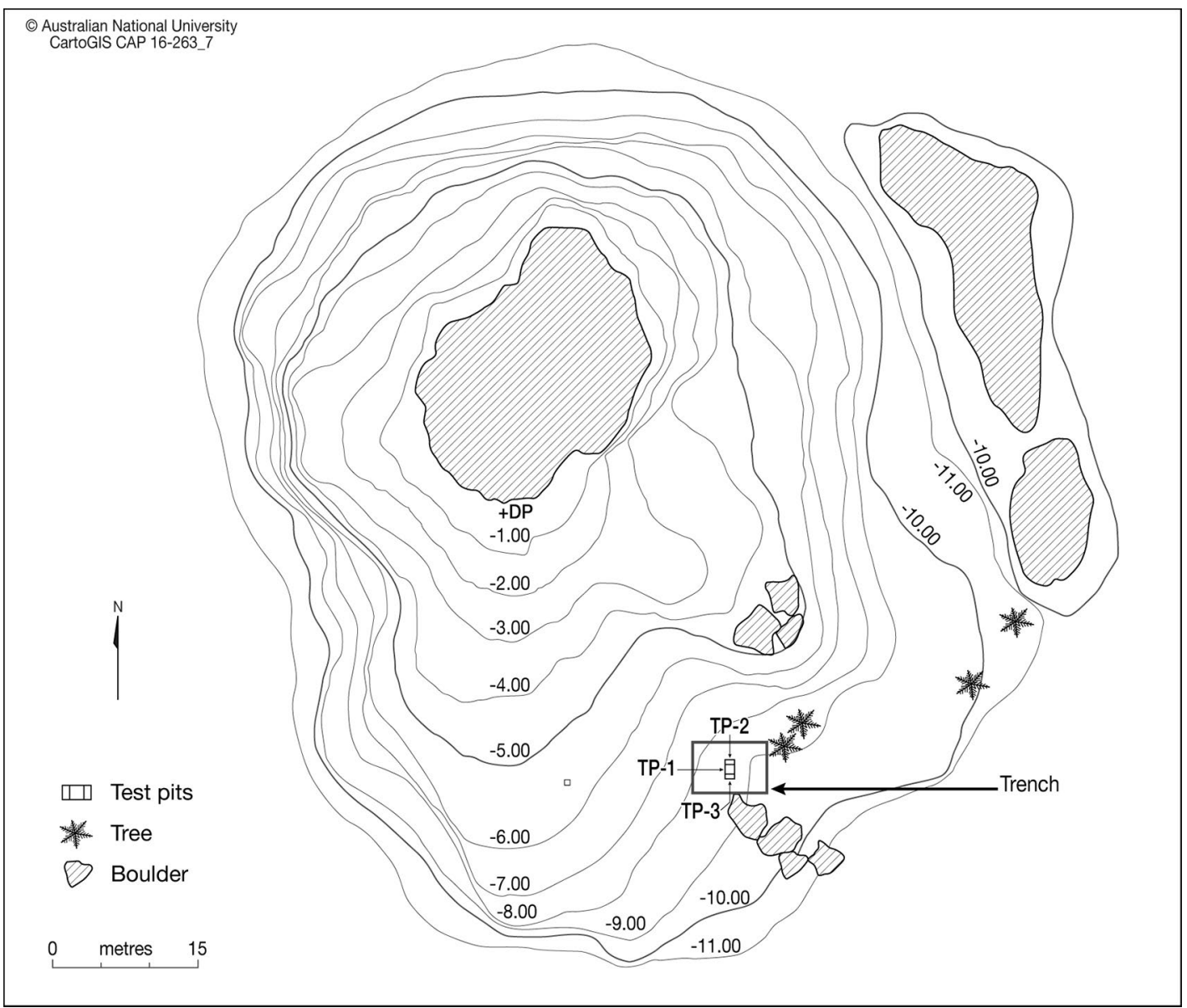

Figure 15.8: Bukit Tiwing and the excavated test pits.

Source: Jennifer Sheehan, CartoGIS, College of Asia and the Pacific, The Australian National University; based on original by Manado Archaeology Office.

We first opened a $1 \mathrm{~m} \times 1 \mathrm{~m}$ test pit (TP1), then later we expanded the test pit to excavate the northern and southern sides of TP 1 by $50 \mathrm{~cm}$, to produce a $2 \mathrm{mx} 1 \mathrm{~m}$ test trench. The smaller test pits are named TP2 (north) and TP3 (south). Excavation was undertaken with $10 \mathrm{~cm}$ spits to a maximum depth of $1 \mathrm{~m}$ below the surface. During the excavation, we first applied dry screening through both the $5 \mathrm{~mm}$ and $3 \mathrm{~mm}$ size meshes, but owing to the wetness of the excavated sediment, we later desisted from using the $3 \mathrm{~mm}$ size mesh. Our excavation identified three cultural layers: Layer 1 as top soil; Layer 2 as blackish organic soil containing lots of shells, potsherds and animal bones; and Layer 3 as a sticky yellowish soil containing only small quantities of potsherds.

Charcoal samples were collected from all of the test pits down to Spit 7 and some were also collected from Spit 8. A total of four AMS dates were obtained from charcoal, while two radiocarbon dates were taken from marine shells (Table 15.3). The AMS determinations from charcoal are c. 300 BP from Layer 2, and c. 350-550 BP from Layer 3. On the other hand, the radiocarbon dates from marine shell, around $700 \mathrm{BP}$ from Layer 2 at $50 \mathrm{~cm}$ depth, are at least 300 years older than the corresponding AMS determinations from charcoal. 
Table 15.3: Radiocarbon and AMS dates from Bukit Tiwing.

\begin{tabular}{|l|l|c|r|r|r|}
\hline Lab. Code & Sample & Layer & \multicolumn{1}{c|}{ Location } & \multicolumn{1}{c|}{ Date (BP) } & Age (cal AD) ${ }^{(\text {a) }}$ \\
\hline TERRA-070407a10 & Marine shell & 2 & TP2/Spit 5 & $688 \pm 33$ & - \\
\hline TERRA-070407a13 & Marine shell & 2 & TP3/Spit 5 & $700 \pm 33$ & - \\
\hline Wk-15740 & Charcoal & 3 & TP3/Spit 7 & $539 \pm 81$ & $1276-1615$ \\
\hline TERRA-070407a23 & Charcoal & 3 & TP2/Spit 7 & $343 \pm 30$ & $1466-1639$ \\
\hline Wk-15741 & Charcoal & 3 & TP3/Spit 6 & $371 \pm 31$ & $1446-1634$ \\
\hline TERRA-070407a24 & Charcoal & 2 & TP2/Spit 4 & $294 \pm 33$ & $1489-1661$ \\
\hline
\end{tabular}

(a) 95\% calibrated range from Intcal13 (Bronk Ramsey 2016).

Source: Rintaro 0no.

Our Carbon-14 dates from Leang Buida and Bukit Tiwing clearly show that marine shell dates carry a marine reservoir effect that usually makes these dates appear hundreds of years older than their counterpart dates on charcoal (e.g. Nakamura 2003; Yoneda et al. 2004). Accordingly, we endorse the charcoal dates rather than the unreliable marine shell dates, and date the main occupation of Bukit Tiwing to around AD 1500-1600 or the 16th-17th centuries.

The cultural artefacts excavated from the site include 3178 potsherds including the Rarangunusa type, 70 imported ceramic sherds, six fragments of iron, two bone tools, 19 lithic waste flakes, 20 stone tools including nuts cracker or hammerstones, seven coral tools (mainly pestles) and a piece of baked clay spindle whorl (Table 15.4). Fragment of iron were excavated only down to Spit 4 (Layer 2), while imported ceramics were excavated down to Spit 6 (upper Layer 3). Animal bones and marine shells together with stone and coral tools were mainly collected from Layer 2 (Spits 3-5) and decreased in frequency in Layer 3 (Spits 6-10). Earthenware potsherds are the only item collected from all of the spits.

Table 15.4: Excavated cultural artefacts from Bukit Tiwing.

\begin{tabular}{|c|c|c|c|c|c|c|c|c|c|c|c|}
\hline TP1, 2, 3 & L & & & L2 & & & & L3 & & & Total \\
\hline Category & Spit 1 & Spit 2 & Spit 3 & Spit 4 & Spit 5 & Spit 6 & Spit 7 & Spit 8 & Spit 9 & Spit 10 & \\
\hline Potsherd & 169 & 692 & 1025 & 352 & 382 & 282 & 107 & 116 & 49 & 4 & 3178 \\
\hline Ceramic & 2 & 20 & 30 & 10 & 5 & 3 & & & & & 70 \\
\hline Iron & & & 1 & 5 & & & & & & & 6 \\
\hline Stone waste & & 3 & & 2 & 6 & 6 & 1 & & 1 & & 19 \\
\hline Stone tool & 4 & 3 & 2 & 2 & 2 & 5 & 1 & & & 1 & 20 \\
\hline Coral pestle & 1 & & 2 & & 3 & 1 & & & & & 7 \\
\hline Bone tool & & & 1 & 1 & & & & & & & 2 \\
\hline Spindle whorl & & & & 1 & & & & & & & 1 \\
\hline Total & 176 & 718 & 1061 & 373 & 398 & 297 & 109 & 116 & 50 & 5 & 3303 \\
\hline
\end{tabular}

Source: Authors' data.

Most of the decorated sherds can be identified as Rarangunusa-style pottery characterised by parallel wavy incisions possibly made by two-pronged tools, without other incisions or decorations on their surface (see Ono et al. 2013). Most of the imported ceramics are blue-and-white wares from the Qing Dynasty (late 17th to 19th centuries) that represent cheap mass productions (Figure 15.9), some of them possibly made in Zhangzhou, Fujian Province in China. However, the imported ceramics also include older celadon sherds with fish and flower designs. 


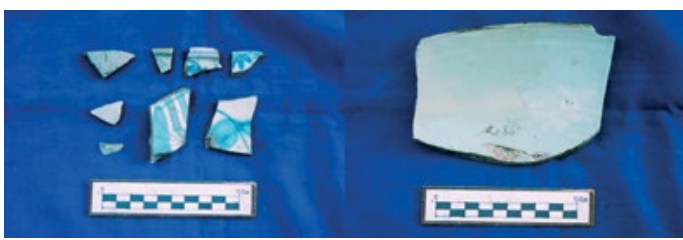

Figure 15.9: Excavated Qing Dynasty sherds from Bukit Tiwing.

Source: Rintaro 0no.

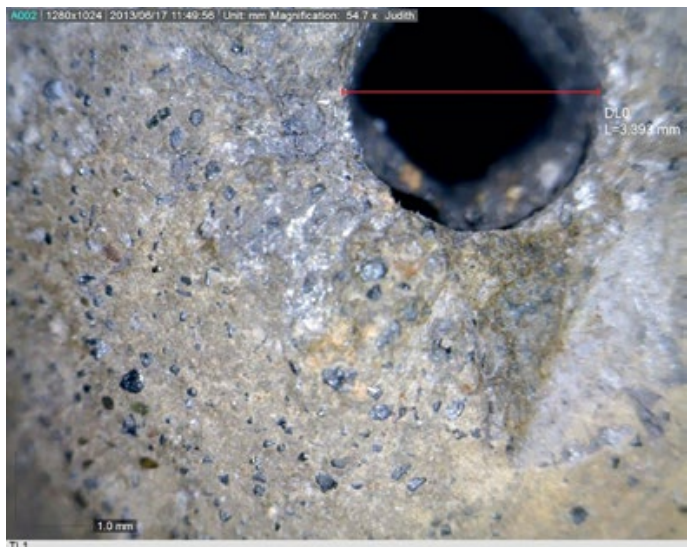

Figure 15.10: Excavated spindle whorl from Bukit Tiwing and possible use-wear marks beside the central perforation.

Source: Judith Cameron, with permission.
Besides the pottery, a piece of baked clay spindle whorl (Figure 15.10) was excavated from the bottom of Layer 2 (TP3/Spit5). Its height is $17 \mathrm{~mm}$, its maximum width is $20 \mathrm{~mm}$, and it has a single hole with a diameter of 2.5-4 mm in its middle (Ono et al. 2013). A spindle whorl is a tool used for spinning and twisting fibres into yarn; many kinds of spindle whorl made of clay, wood and other materials have been found in archaeological sites around the world. Clay spindle whorls are a common feature of Neolithic and Bronze Age levels in Mainland Southeast Asian sites (Bellwood 2017; Cameron 2005, 2011). They are less common in ISEA sites (e.g. Oliver 1989; Cameron and Mijares 2006), although the Sunget site on Batan and the Savidug Dune site on Sabtang, in the Batanes Islands at the far north of the Philippines, produced some clay spindle whorls by 1200 BC (Cameron 2013). Compared with these spindle whorls, the Bukit Tiwing specimen is much younger, but it is so far the first excavated case of a clay spindle whorl in the Sangihe-Talaud Islands.

\section{Marine resource use in Leang Buida and Bukit Tiwing}

Fish and shell remains were excavated from both Leang Buida and Bukit Tiwing. Leang Buida produced the larger Numbers of Individual Specimens (NISP): 21,487 NISP of shell remains (about $50 \mathrm{~kg}$ ) and 356 NISP of fish remains. Bukit Tiwing produced only 3,301 NISP of shell remains and 121 NISP of fish remains. We first report on shell exploitation at Leang Buida and Bukit Tiwing, and then focus on the fish remains.

\section{Shellfish exploitation}

Table 15.5 shows the NISP of each family by layer for the 23 families (and 117 taxa) of shell excavated and identified at Leang Buida. Excluding the Ellobiidae land snail species, which was possibly a natural inclusion (especially in the upper layers), Neritidae, Turbinidae, Chitonidae and Cypraeanidae were the major shell families exploited at Leang Buida. Since a large number and variety of shells were recovered from the site, we show detailed identifications only for Neritidae and Turbinidae, the two main marine shell families (Table 15.6). Nerita undata and Nerita albicilla were the two main species for the Neritidae, and Turbo stenogyrus and Turbo argyrostoms for the Turbinidae. However, the site also produced a number of opercula belonging to Turbo malmoratus shells, which is a larger species and so might also have been important for human subsistence as its larger size would indicate a relatively high meat value. 
Table 15.5: List of invertebrate remains from Leang Buida (NISP).

\begin{tabular}{|c|c|c|c|c|c|c|c|c|c|}
\hline Taxa/Family & L1 & L2 & L3 & Total & Taxa/Family & L1 & L2 & L3 & Total \\
\hline (Gastropoda) & & & & & (Bivalvia) & & & & \\
\hline Neritidae & 2720 & 4805 & 1794 & 9319 & Arcidae & 0 & 48 & 15 & 63 \\
\hline Turbinidae & 608 & 1729 & 572 & 2909 & Tridacnidae & 16 & 21 & 8 & 45 \\
\hline Cypraenidae & 26 & 193 & 61 & 280 & Veneridae & 1 & 15 & 3 & 19 \\
\hline Vasidae & 28 & 91 & 34 & 153 & Mitridae & 0 & 1 & 0 & 1 \\
\hline Fissurellidae & 60 & 43 & 44 & 147 & & & & & \\
\hline Trochidae & 17 & 45 & 19 & 81 & (Polyplacophora) & & & & \\
\hline Conidae & 7 & 30 & 45 & 82 & Chitonidae & 123 & 249 & 4 & 376 \\
\hline Haliotidae & 5 & 13 & 17 & 35 & & & & & \\
\hline Patellidae & 6 & 11 & 1 & 18 & (Echinoidea) & & & & \\
\hline Nassariidae & 0 & 3 & 0 & 3 & Sea urchin & 2 & 12 & 2 & 14 \\
\hline Cassididae & 1 & 1 & 0 & 2 & & & & & \\
\hline Fasciolariidae & 2 & 0 & 0 & 2 & (Malacostraca) & & & & \\
\hline Tonnidae & 0 & 1 & 0 & 1 & Crab & 22 & 13 & 2 & 37 \\
\hline Hipponicidae & 1 & 0 & 0 & 1 & & & & & \\
\hline Harpidae & 1 & 0 & 0 & 1 & (Ellobiidae) & & & & \\
\hline Pylanidellidae & 0 & 1 & 0 & 1 & Land snail & 3962 & 1985 & 340 & 6287 \\
\hline Strombidae & 1 & 0 & 0 & 1 & & & & & \\
\hline Sub-total & 3483 & 6966 & 2587 & 13036 & Sub-total & 4126 & 2344 & 374 & 6844 \\
\hline
\end{tabular}

Source: Rintaro 0no.

Table 15.6: List of excavated species of Neritidae and Turbinidae, Leang Buida (NISP).

\begin{tabular}{|l|l|r|r|r|r|}
\hline Family & Species & \multicolumn{1}{|c|}{ L1 } & \multicolumn{1}{|c|}{ L2 } & \multicolumn{1}{c|}{ Lotal } \\
\hline Neritidae & & $\mathbf{2 7 2 0}$ & $\mathbf{4 8 0 5}$ & $\mathbf{1 7 9 4}$ & $\mathbf{9 3 1 9}$ \\
\hline & Nerita undata & 1209 & 1769 & 667 & 3645 \\
\hline & Nerita albicilla & 645 & 1246 & 537 & 2428 \\
\hline & Nerita lineata & 367 & 961 & 283 & 1611 \\
\hline & Ritena costana & 449 & 703 & 266 & 1418 \\
\hline & Septaria porcellana & 5 & 67 & 36 & 108 \\
\hline & Neritopsts radula & 27 & 42 & 5 & 74 \\
\hline & $?$ & 16 & 17 & 0 & 33 \\
\hline & $?$ & 1 & 0 & 0 & 1 \\
\hline & $?$ & 1 & 0 & 0 & 1 \\
\hline & & 608 & 1729 & 572 & 2909 \\
\hline & Turbo stenogyrus & 210 & 875 & 415 & 1500 \\
\hline & Turbo argyrostoms & 168 & 429 & 74 & 671 \\
\hline & Turbo marmoratus & 50 & 141 & 14 & 205 \\
\hline & Turbo marmoratus (0) & 38 & 68 & 2 & 108 \\
\hline & Turbo sp. & 94 & 130 & 1 & 225 \\
\hline & Turbo sp. & 19 & 46 & 0 & 65 \\
\hline & Turbo stosus & 29 & 40 & 66 & 135 \\
\hline
\end{tabular}

$(0)^{*}=$ operculum.

Source: Rintaro Ono. 
Tables 15.7 and 15.8 show the NISP by layer for the 20 families and 43 taxa of shell excavated and identified at Bukit Tiwing. Turbo, principally Turbo sp., Turbo chrysostomus and Turbo stosus is the most frequently identified family at Bukit Tiwing, followed by Neritidae including Nerita undata and Nerita albicilla. The Chitonidae are also a major shell family exploited at Bukit Tiwing. As for the Turbo shells, it should be noted that some species with large NISP number are not yet identified to species level. In terms of meat value, however, Turbo and Trochus sp. shells could be the most important at the site.

Table 15.7: List of invertebrate remains from Bukit Tiwing (NISP).

\begin{tabular}{|c|c|c|c|c|c|c|c|c|c|c|}
\hline \multirow[t]{2}{*}{ Family } & \multirow[t]{2}{*}{ Species } & \multicolumn{2}{|c|}{ L1 } & \multicolumn{3}{|c|}{$\mathrm{L} 2$} & \multicolumn{3}{|c|}{ L3 } & \multirow[t]{2}{*}{ Total } \\
\hline & & 1 & 2 & 3 & 4 & 5 & 6 & 7 & 8 & \\
\hline \multicolumn{11}{|l|}{ Gastropoda } \\
\hline Turbinidae & See Table 15.8 & 102 & 109 & 440 & 397 & 503 & 248 & 19 & 0 & 1818 \\
\hline Neritidae & See Table 15.8 & 0 & 0 & 40 & 44 & 295 & 78 & 21 & 0 & 478 \\
\hline Muricidae & Muricidae sp. & 2 & 2 & 21 & 43 & 81 & 35 & 1 & 0 & 185 \\
\hline Trochidae & See Table 15.8 & 0 & 2 & 18 & 19 & 21 & 35 & 5 & 0 & 100 \\
\hline Conidae & Conidae sp. & 1 & 1 & 15 & 17 & 18 & 13 & 0 & 0 & 65 \\
\hline Terebridae & $?$ & 1 & 0 & 1 & 1 & 22 & 30 & 4 & 0 & 59 \\
\hline Strombidae & See Table 15.8 & 4 & 0 & 4 & 8 & 17 & 3 & 0 & 0 & 36 \\
\hline Fasciolariidae & See Table 15.8 & 0 & 0 & 2 & 6 & 4 & 4 & 2 & 0 & 18 \\
\hline Cypraeidae & See Table 15.8 & 0 & 0 & 3 & 4 & 5 & 5 & 0 & 0 & 17 \\
\hline Tridacnidae & See Table 15.8 & 0 & 1 & 2 & 5 & 4 & 0 & 0 & 0 & 12 \\
\hline Veneridae? & ? & 0 & 0 & 1 & 3 & 0 & 2 & 0 & 0 & 6 \\
\hline Ranellidae? & $?$ & 0 & 2 & 1 & 0 & 0 & 2 & 0 & 0 & 5 \\
\hline Acmaeidae & Patelloida saccharina & 0 & 0 & 0 & 0 & 1 & 3 & 1 & 0 & 5 \\
\hline Rapidaea & Latiaxis armatus? & 0 & 0 & 0 & 1 & 2 & 1 & 0 & 0 & 4 \\
\hline Psammobiidae & Asaphis deflorata & 0 & 0 & 1 & 0 & 1 & 2 & 0 & 0 & 4 \\
\hline Mactridae? & $?$ & 0 & 0 & 0 & 1 & 0 & 1 & 1 & 0 & 3 \\
\hline Mitridae & $?$ & 0 & 0 & 0 & 0 & 1 & 0 & 0 & 0 & 1 \\
\hline Unknown & $?$ & 0 & 0 & 1 & 0 & 0 & 0 & 0 & 0 & 1 \\
\hline \multicolumn{11}{|l|}{ Polyplacophora } \\
\hline Chitonidae & Acanthopleura/Liolophura & 0 & 0 & 4 & 22 & 187 & 134 & 6 & 0 & 353 \\
\hline \multicolumn{11}{|l|}{ Land snail } \\
\hline Ellobiidae & Pythia panthrina & 12 & 3 & 0 & 5 & 0 & 1 & 0 & 0 & 21 \\
\hline Land snail & $?$ & 1 & 0 & 0 & 0 & 0 & 0 & 0 & 0 & 1 \\
\hline Total & & 123 & 120 & 554 & 576 & 1162 & 597 & 60 & 0 & 3192 \\
\hline
\end{tabular}

Source: Rintaro 0no.

Table 15.8: List of identified marine gastropod species from Bukit Tiwing (NISP).

\begin{tabular}{|c|c|c|c|c|c|c|c|c|c|c|}
\hline \multirow[t]{2}{*}{ Family } & \multirow[t]{2}{*}{ Species } & \multicolumn{2}{|c|}{ L1 } & \multicolumn{3}{|c|}{ L2 } & \multicolumn{3}{|c|}{ L3 } & \multirow[t]{2}{*}{ Total } \\
\hline & & 1 & 2 & 3 & 4 & 5 & 6 & 7 & 8 & \\
\hline \multirow[t]{8}{*}{ Turbinidae } & Turbo sp. & 102 & 98 & 303 & 216 & 302 & 159 & 12 & 0 & 1192 \\
\hline & Turbo chrysostomus & 0 & 6 & 70 & 64 & 65 & 24 & 4 & 0 & 233 \\
\hline & Turbo stosus & 0 & 2 & 28 & 61 & 74 & 40 & 3 & 0 & 208 \\
\hline & Turbo sp. & 0 & 3 & 36 & 30 & 28 & 25 & 0 & 0 & 122 \\
\hline & Turbo stengyrus & 0 & 0 & 2 & 24 & 34 & 0 & 0 & 0 & 60 \\
\hline & Turbo marmoratus & 0 & 0 & 0 & 2 & 0 & 0 & 0 & 0 & 2 \\
\hline & Turbo sp. & 0 & 0 & 1 & 0 & 0 & 0 & 0 & 0 & 1 \\
\hline & & 102 & 109 & 440 & 397 & 503 & 248 & 19 & 0 & 1818 \\
\hline
\end{tabular}




\begin{tabular}{|c|c|c|c|c|c|c|c|c|c|c|}
\hline \multirow[t]{2}{*}{ Family } & \multirow[t]{2}{*}{ Species } & \multicolumn{2}{|c|}{ L1 } & \multicolumn{3}{|c|}{$\mathrm{L} 2$} & \multicolumn{3}{|c|}{ L3 } & \multirow[t]{2}{*}{ Total } \\
\hline & & 1 & 2 & 3 & 4 & 5 & 6 & 7 & 8 & \\
\hline \multirow[t]{5}{*}{ Neritidae } & Nerita undata & 0 & 0 & 20 & 11 & 249 & 57 & 12 & 0 & 349 \\
\hline & Nerita albicilla & 0 & 0 & 20 & 33 & 46 & 19 & 9 & 0 & 127 \\
\hline & Ritena costana & 0 & 0 & 0 & 0 & 0 & 1 & 0 & 0 & 1 \\
\hline & Ritena squamulta & 0 & 0 & 0 & 0 & 0 & 1 & 0 & 0 & 1 \\
\hline & & 0 & 0 & 40 & 44 & 295 & 78 & 21 & 0 & 478 \\
\hline \multirow[t]{5}{*}{ Trochidae } & Trochus maculatus & 0 & 1 & 1 & 17 & 7 & 13 & 3 & 0 & 42 \\
\hline & Trochus niloticus maximus & 0 & 1 & 17 & 2 & 13 & 9 & 1 & 0 & 43 \\
\hline & Umbonium sp. & 0 & 0 & 0 & 0 & 1 & 7 & 1 & 0 & S \\
\hline & Tectus pyramis & 0 & 0 & 0 & 0 & 0 & 6 & 0 & 0 & 6 \\
\hline & & 0 & 2 & 18 & 19 & 21 & 35 & 5 & 0 & 100 \\
\hline \multirow[t]{3}{*}{ Strombidae } & Lambis lambis & 4 & 0 & 3 & 3 & 3 & 0 & 0 & 0 & 13 \\
\hline & Storombus decorus & 0 & 0 & 1 & 4 & 14 & 3 & 0 & 0 & 22 \\
\hline & \begin{tabular}{|l|} 
(Totals include 1?) \\
\end{tabular} & 4 & 0 & 4 & 8 & 17 & 3 & 0 & 0 & 36 \\
\hline \multirow[t]{3}{*}{ Fasciolariidae } & Fusinus undatus & 0 & 0 & 0 & 3 & 2 & 0 & 0 & 0 & 5 \\
\hline & Latirus nagasakiensis & 0 & 0 & 0 & 3 & 2 & 4 & 2 & 0 & 11 \\
\hline & (Totals include 2?) & 0 & 0 & 2 & 6 & 4 & 4 & 2 & 0 & 18 \\
\hline \multirow[t]{4}{*}{ Cypraeidae } & Cургаеа caputserpentis & 0 & 0 & 3 & 2 & 2 & 2 & 0 & 0 & $S$ \\
\hline & Сургаеа /упх & 0 & 0 & 0 & 1 & 2 & 0 & 0 & 0 & 3 \\
\hline & Сургаеа tigris & 0 & 0 & 0 & 1 & 0 & 0 & 0 & 0 & 1 \\
\hline & (Totals include 4?) & 0 & 0 & 3 & 4 & 5 & 5 & 0 & 0 & 17 \\
\hline \multirow[t]{5}{*}{ Tridacnidae } & Tridacna crocea & 0 & 0 & 0 & 5 & 3 & 0 & 0 & 0 & $\varepsilon$ \\
\hline & Hippopus hippopus & 0 & 1 & 0 & 0 & 0 & 0 & 0 & 0 & 1 \\
\hline & Tridacna gigas & 0 & 0 & 1 & 0 & 0 & 0 & 0 & 0 & 1 \\
\hline & Tridacna maxima & 0 & 0 & 1 & 0 & 1 & 0 & 0 & 0 & 2 \\
\hline & & 0 & 1 & 2 & 5 & 4 & 0 & 0 & 0 & 12 \\
\hline
\end{tabular}

Source: Rintaro 0no.

\section{Fish exploitation}

At Leang Buida, 356 NISP of identified fish bones (246 Minimum Number of Individuals $(\mathrm{MNI})$ ) were excavated. They were identified into 16 fish families (all marine species) including Scaridae, Serranidae, Labridae, Lethrinidae, Lutjanidae, Acanthuridae, Balistidae, Diodontidae, Holocentridae, Scombridae, Muraenidae, Siganidae, Carangidae, Sphyraenidae, and Sharks, mainly Carcharhinidae (see Table 15.9). As for the inshore fish species, the Serranids (groupers) and Lutjanids (snappers) are the two most frequent families. These are more commonly captured by angling rather than netting and spearing, based on ethno-archaeological studies in ISEA and the tropical Pacific. Holocentrids and Labrids are also commonly captured by angling, while Lethrinids and Balistids are usually captured by both angling and netting, depending on size and species. Other inshore fish species such as the Scarids, Diodontids and Acanthurids are mainly omnivorous fishes in shallow coral reef habitat, and are commonly captured by netting and spearing (Kirch and Dickinson 1976; Kirch and Dye 1979; Dye 1983; Goto 1986, 1990; Masse 1986, 1989; Rolett 1989; Ono 2010, 2011). 
Table 15.9: Identified fish remains from Leang Buida (MNI).

\begin{tabular}{|c|c|c|c|c|c|c|c|c|c|c|c|c|c|}
\hline \multirow[t]{2}{*}{ Family } & \multirow[t]{2}{*}{ Habitation } & \multicolumn{2}{|c|}{ L1 } & \multicolumn{5}{|c|}{ L2 } & \multicolumn{4}{|c|}{ L3 } & \multirow{2}{*}{$\begin{array}{l}\text { Total } \\
\text { MNI }\end{array}$} \\
\hline & & 1 & 2 & 3 & 4 & 5 & 6 & 7 & 8 & 9 & 10 & 11 & \\
\hline \multicolumn{14}{|l|}{ (Inshore) } \\
\hline Serranidae & Inshore/bottom & 2 & 11 & 10 & 13 & 10 & 7 & 6 & 5 & 5 & 0 & 1 & 70 \\
\hline Lutjanidae & Inshore/reef & 0 & 3 & 4 & 6 & 4 & 1 & 3 & 4 & 1 & 0 & 0 & 26 \\
\hline Scaridae & Inshore/reef & 0 & 4 & 0 & 2 & 1 & 3 & 5 & 0 & 3 & 1 & 0 & 19 \\
\hline Diodontidae & Inshore/reef & 0 & 1 & 1 & 0 & 1 & 3 & 4 & 4 & 3 & 1 & 1 & 19 \\
\hline Labridae & Inshore/bottom & 1 & 1 & 4 & 5 & 3 & 0 & 2 & 1 & 1 & 0 & 0 & 18 \\
\hline Balistidae & Inshore/bottom & 0 & 1 & 2 & 5 & 2 & 0 & 4 & 4 & 0 & 0 & 0 & 18 \\
\hline Lethrinidae & Inshore/reef & 0 & 1 & 3 & 3 & 2 & 2 & 1 & 4 & 1 & 0 & 0 & 17 \\
\hline Acanthuridae & Inshore/reef & 0 & 0 & 1 & 3 & 2 & 0 & 4 & 1 & 0 & 0 & 0 & 11 \\
\hline Holocentridae & Inshore & 0 & 0 & 2 & 0 & 2 & 2 & 1 & 0 & 1 & 0 & 0 & 8 \\
\hline$?$ & & 0 & 0 & 2 & 2 & 1 & 0 & 2 & 0 & 0 & 0 & 0 & 7 \\
\hline Muraenidae & Inshore/bottom & 0 & 0 & 0 & 1 & 2 & 0 & 1 & 0 & 0 & 0 & 0 & 4 \\
\hline Siganidae & Inshore/reef & 0 & 0 & 0 & 1 & 1 & 0 & 1 & 0 & 0 & 0 & 0 & 3 \\
\hline \multicolumn{14}{|l|}{ (Inshore-Pelagic) } \\
\hline Sharks/Carcharhinidae & Inshore-Pelagic & 0 & 0 & 0 & 0 & 1 & 2 & 1 & 1 & 1 & 2 & 1 & 9 \\
\hline Carangidae & Inshore-Pelagic & 1 & 2 & 0 & 4 & 1 & 0 & 0 & 0 & 0 & 0 & 0 & 8 \\
\hline Scombridae & Pelagic & 0 & 1 & 2 & 2 & 1 & 0 & 0 & 0 & 0 & 0 & 0 & 6 \\
\hline Sphyгaenidae & Inshore-Pelagic & 0 & 0 & 1 & 1 & 0 & 0 & 1 & 0 & 0 & 0 & 0 & 3 \\
\hline Total & & 4 & 25 & 32 & 48 & 34 & 20 & 36 & 24 & 16 & 4 & 3 & 246 \\
\hline
\end{tabular}

Source: Rintaro 0no.

It is also important to note that Leang Buida produced pelagic species including Scombrids (tunas), Carangids (trevallies) and Sphyraenids (barracudas), as well as sharks, all of which are commonly captured by angling or trolling. Except sharks, however, no pelagic fish were excavated from Layer 3, which dates to around $\mathrm{AD}$ 1000. Layer 2 produced the highest number and greatest variety of fish bones, suggesting that more active fishing possibly with various kinds of fishing methods was practised after AD 1600 by the Leang Buida occupants.

Compared with Leang Buida, far fewer identified fish bones were recovered from Bukit Tiwing (40 NISP; 25 MNI) but they include the 10 fish families of Scaridae, Serranidae, Lethrinidae, Lutjanidae, Acanthuridae, Balistidae, Diodontidae, Scombridae, Tetradontidae and Holocentridae (Table 15.10). Most of these are inshore fish species, which inhabit shallow reef or reef edge and are captured mainly by netting, angling and spearing. Lethrinids, especially Monotaxis species with their large jaws, Lutjanids, Serranids, Holocentrids and Labrids are commonly captured by angling, while Scarids, Acanthurids and Diodontids are mainly captured by netting and spearing. Muraenids (moray eels) are usually captured by spearing. As for pelagic species, some Scombrid bones were excavated from Layer 2 .

Table 15.10: Identified fish remains from Bukit Tiwing (NISP, MNI in brackets).

\begin{tabular}{|c|c|c|c|c|c|c|c|c|c|c|}
\hline \multirow[t]{2}{*}{ Rank } & \multirow[t]{2}{*}{ Таха/Spit } & \multicolumn{2}{|c|}{ L1 } & \multicolumn{3}{|c|}{$\mathrm{L} 2$} & \multicolumn{3}{|c|}{ L3 } & \multirow[t]{2}{*}{ Total } \\
\hline & & 1 & 2 & 3 & 4 & 5 & 6 & 7 & 8 & \\
\hline \multirow[t]{2}{*}{1} & Lethrinidae & 0 & 0 & $3(2)$ & 1 & 0 & 0 & 0 & 0 & $4(3)$ \\
\hline & Monotaxis grandoculis & 0 & 0 & $2(1)$ & 0 & 0 & 0 & 0 & 0 & $2(1)$ \\
\hline 1 & Scaridae & 0 & $2(1)$ & $4(2)$ & 0 & 1 & 0 & 0 & 0 & $7(4)$ \\
\hline 3 & Acanthridae & 0 & 0 & $2(1)$ & 0 & 1 & 1 & 0 & 0 & $4(3)$ \\
\hline 3 & Lutjanidae & 0 & 0 & 0 & 1 & $2(1)$ & 1 & 0 & 0 & $4(3)$ \\
\hline 3 & Serranidae & 1 & 0 & 1 & 1 & 0 & 0 & 0 & 0 & $3(3)$ \\
\hline
\end{tabular}




\begin{tabular}{|c|c|c|c|c|c|c|c|c|c|c|}
\hline \multirow[t]{2}{*}{ Rank } & \multirow[t]{2}{*}{ Taха/Spit } & \multicolumn{2}{|c|}{ L1 } & \multicolumn{3}{|c|}{ L2 } & \multicolumn{3}{|c|}{ L3 } & \multirow[t]{2}{*}{ Total } \\
\hline & & 1 & 2 & 3 & 4 & 5 & 6 & 7 & 8 & \\
\hline 6 & Diodontidae & 0 & 0 & $4(1)$ & $2(1)$ & 0 & 0 & 0 & 0 & $6(2)$ \\
\hline 6 & Balistidae & 0 & 0 & 1 & 0 & 1 & 0 & 0 & 0 & $2(2)$ \\
\hline 8 & Scombridae & 0 & 0 & $4(1)$ & 0 & 0 & 0 & 0 & 0 & $4(1)$ \\
\hline 8 & Muraenidae & 0 & 0 & 0 & 0 & 1 & 0 & 0 & 0 & 1 \\
\hline 8 & Holocentridae & 0 & 0 & 0 & 1 & 0 & 0 & 0 & 0 & 1 \\
\hline \multirow[t]{2}{*}{8} & Labridae & 0 & 0 & 0 & 0 & 0 & 1 & 0 & 0 & 1 \\
\hline & Total & 1 & 2 & 21 & 6 & 6 & 3 & 0 & 0 & $39(25)$ \\
\hline
\end{tabular}

Source: Rintaro 0no.

\section{Terrestrial resource use at Leang Buida and Bukit Tiwing}

Leang Buida produced 409 NISP of mammal, bird and sea turtle remains, and over $80 \%$ of them were unearthed from Layers 2 and 3 (Table 15.11). Although the total number and volume of animal remains is limited, the available identifications indicate that at least four taxapig (Sus scrofa), goat (Capra hircus), rat (Murids) and sea turtles-were exploited at the site. A significant finding involves the goat teeth and bones from Layer 3 dated to around AD 1000, which indicate that goats were introduced to the Talaud Islands by at least the 11th century AD. The earliest securely dated goats in ISEA (Bali) date back to $200 \mathrm{BC}$ in association with rouletted ware imported from India (Calo et al. 2015); thus, these goats could have been introduced from India. However, goats possibly became popular as food meat after the expansion of Islam, notably in Western Indonesia. Goats are also a popular domesticated animal in the Philippine Islands and in remote island ecosystems as they can thrive in grassland. The earliest ISEA goat remains of possible Chinese origin have been identified at a couple of sites on the Batanes Islands after AD 1000 (Piper et al. 2013). Similarly, our excavations provide archaeological evidence for the introduction of goats to the Talaud Islands by around AD 1000. Although the origin of the Talaud goats is as yet unknown, they could be of Chinese origin in view of the proximity of the Talauds to the Philippines Islands.

Table 15.11: Identified taxon and unidentified animal bones from Leang Buida.

\begin{tabular}{|c|c|c|c|c|c|c|c|c|c|c|c|c|}
\hline \multirow[t]{2}{*}{ Taxa } & \multicolumn{2}{|c|}{$\mathrm{L} 1$} & \multicolumn{5}{|c|}{ L2 } & \multicolumn{4}{|c|}{ L3 } & \multirow[t]{2}{*}{ NISP (MNI) } \\
\hline & 1 & 2 & 3 & 4 & 5 & 6 & 7 & 8 & 9 & 10 & 11 & \\
\hline Pig & 0 & 3 & 0 & 2 & 3 & 1 & 1 & 4 & 2 & 0 & 0 & $16(4)$ \\
\hline Goat & 6 & 3 & 2 & 1 & 0 & 0 & 0 & 0 & 1 & 0 & 0 & $13(4)$ \\
\hline Rat & 0 & 0 & 1 & 11 & 0 & 0 & 0 & 0 & 0 & 0 & 0 & $12(1)$ \\
\hline Bird & 0 & 1 & 1 & 0 & 1 & 1 & 1 & 0 & 0 & 0 & 0 & $5(2)$ \\
\hline Sea turtle & 0 & 2 & 3 & 1 & 1 & 1 & 0 & 0 & 0 & 0 & 0 & $8(2)$ \\
\hline Unidentified & 12 & 17 & 33 & 46 & 52 & 100 & 24 & 32 & 24 & 12 & 3 & 355 \\
\hline Total & 18 & 26 & 40 & 61 & 57 & 103 & 26 & 36 & 27 & 12 & 20 & 409 (13) \\
\hline
\end{tabular}

Source: The authors.

Bukit Tiwing produce 1448 NISP (3128 g) of mammal and sea turtle remains, with $77 \%$ of the faunal remains unearthed from Layer 2 (Table 15.12). The identified animals are domesticated pig (Sus scrofa), sea turtle (Chelonioidea sp.), dog (Canis familiaris), goat (Capra hircus) and rat (Muridae). Among these, pigs are the leading species with 101 NISP and 12 MNI, followed by sea turtles with 81 NISP and 5 MNI. Two dog mandible fragments (MNI=1), one goat tooth and one rat tooth were also identified. Nine mandibles/fragments $(\mathrm{MNI}=6)$, tentatively identified as 
primate remains (Macaca sp. or Tarsius sp.), were also unearthed. ${ }^{2}$ Anatomical elements other than teeth and mandibles are not yet analysed and identified to taxa; although impressionistically, pig seems to account for a larger number and volume than any other species.

The Bukit Tiwing identifications point to pig as the major source of animal protein followed by sea turtle and monkey. Detailed analysis of the excavated pig teeth indicates that most of the pigs were killed at a young age of around 6-20 months old. Many of pig femur bones have bite marks from dogs. Also, the dog mandible fragments have some cut marks, which suggest that dogs were also eaten in the Talauds in times past. Another interesting finding is the goat tooth, derived from domesticated goats in the Talaud Islands or goat meat imported from some other location during the 16 th or 17 th century AD.

Table 15.12: Identified taxon and unidentified animal bones from Bukit Tiwing.

\begin{tabular}{|c|c|c|c|c|c|c|c|c|c|}
\hline \multirow[t]{2}{*}{ Taxon } & \multicolumn{2}{|c|}{ L1 } & \multicolumn{3}{|c|}{ L2 } & \multicolumn{3}{|c|}{ L3 } & \multirow[t]{2}{*}{ Total } \\
\hline & 1 & 2 & 3 & 4 & 5 & 6 & 7 & 8 & \\
\hline Pig (tooth) & 5 & 13 & 15 & 29 & 10 & 3 & 0 & 0 & 75 \\
\hline Pig (mandible) & 0 & 4 & 2 & 16 & 4 & 0 & 0 & 0 & 26 \\
\hline Pig (total) & 5 & 17 & 17 & 45 & 14 & 3 & 0 & 0 & $101(12) *$ \\
\hline Sea Turtle & 0 & 3 & 22 & 41 & 10 & 5 & 0 & 0 & $81(5) *$ \\
\hline Macaca/Tarsius? (mandible) & 1 & 0 & 4 & 1 & 2 & 1 & 0 & 0 & $9(6)^{*}$ \\
\hline Dog (mandible) & 0 & 0 & 0 & 1 & 1 & 0 & 0 & 0 & $2(1)^{*}$ \\
\hline Goat (tooth) & 0 & 0 & 1 & 0 & 0 & 0 & 0 & 0 & 1 \\
\hline Rat (tooth) & 0 & 0 & 1 & 0 & 0 & 0 & 0 & 0 & 1 \\
\hline \multicolumn{10}{|l|}{ Unidentified bones } \\
\hline Tooth & 1 & 3 & 9 & 14 & 8 & 1 & 0 & 0 & 36 \\
\hline Vertebra & 0 & 0 & 2 & 1 & 0 & 1 & 0 & 0 & 4 \\
\hline Others & 29 & 174 & 361 & 385 & 184 & 76 & 4 & 0 & 1213 \\
\hline Total & 36 & 197 & 417 & 488 & 219 & 87 & 4 & 0 & 1448 \\
\hline
\end{tabular}

()$^{*}=$ MNI number.

Source: The authors.

All of the larger terrestrial animals were clearly introduced to the Talaud Islands by humans because the only terrestrial mammals native to the Talaud Islands (e.g. Riley 2002) were four species of flying fox (Pteropus spp.), 14 other species of bat, five species of rat and two species of cuscus (Ailurops ursinus and Strigocuscus celebensis). The rat tooth is not identified to species level and we are not sure if it represents a wild species or one that arrived with humans in the past.

\section{Discussion}

Based on our excavation results at Leang Buida and Bukit Tiwing in the Talaud Islands, we now discuss the possible development of marine and terrestrial resource use as well as regional maritime networks in the Sulawesi Sea during the 2nd millennium AD. The lower layer of Leang Buida is dated to around AD 1000, while the upper layers of Leang Buida and Bukit Tiwing date to around AD 1500-1700, hence these sites can provide archaeological evidence on the

2 The literature on Talaud Island mammals does not include any references to the human introduction of tarsiers (including Tarsius sangirensis, native to the Sangihe Islands) or monkeys. However, in 2004, the authors saw a few monkeys (species not clear) along the coast of Salibabu Island. According to the villagers, they used to be pet monkeys kept for collecting coconuts, though our interviews with other Talaud islanders indicated that any such use of monkey is not common and this could be a very recent and exceptional case. Owing to the lack of Macaca and Tarsius specimens in the reference collections available to us, we retain the identification of these Bukit Tiwing mandibles as uncertain and are continuing our efforts to identify them. 
use of shellfish, fish and other animals at these two intervals. The detail of developments during AD 1100-1500 is unclear, but we can at least compare certain changes between AD 1000 and the interval after AD 1500 in the Talauds.

\section{Development of marine and terrestrial use}

In terms of marine resource use, Leang Buida clearly suggests a heightened dependence on inshore fish species at about AD 1000 in the Talaud Islands. However, it should be noted that angling could have been the most important fishing technique in the Talauds where the extent of shallow reef is very limited. High proportions of carnivorous fish species identified as Serranids, Lutjanids and Holocentrids, all of which are captured mainly by angling, confirms this possibility. On the other hand, no fish hooks were recovered from Layer 3 at Leang Buida, which instead yielded a piece of bone-made fish spear and two clay net sinkers, indicating that spear fishing and netting were also actively practised at around AD 1000. This possibility is further supported by the recovery of reef-dwelling omnivorous fish species including Scarids, Diodontids and Acanthurids. The clay net sinkers offer a clear picture on past netting practices in the Talauds and also suggest influence from the north as they have some similarity with the clay and stone net sinkers in the East Asian region dated to AD 500-1200, whereas no evidence of such net sinkers in Eastern Indonesia or the Pacific dated back before AD 1000 has so far been reported.

After around AD 1600, two types of the clay net sinker with more variety in size were used at Leang Buida. Also, evidence for the use of shell-made lure shanks appeared at this time. The remains of fast-swimming pelagic fish species such as tunas (Scombrids) in Layer 2 further support the proposition that the fishing practices after AD 1600 included trolling on the outer reef. Although it is unclear when trolling on the outer reef started in the Talauds, this fishing technique and shell-made lures could reflect influence from the Pacific region, and in particular the Palau Islands in Micronesia, given that a similar type of shell lure shank was produced in Tobi Island after $\mathrm{AD} 1700$, and that the southwest Palau Islands where Tobi is located are the closest Pacific Island group to the Talauds.

Evidence for offshore fishing with trolling lure shanks could date back to $2000 \mathrm{BC}$ in southern Taiwan (e.g. Li 1997, 2002), 1300 BC at early Lapita sites in Melanesia (e.g. Kirch 1997) and possibly from $500 \mathrm{BC}$ in the Marianas (Hung et al. 2011), but no comparable evidence has been found in the northern part of Wallacea including the Talaud Islands and Sulawesi. The reason for this region's widespread absence of fishing gear such as simple one-piece shell-made fish hooks and more complicated two-piece hooks and trolling lures is not yet known, but our finding qualifies as the earliest evidence of fishing with shell-made trolling lures in the Talaud Islands, dating to around $\mathrm{AD} 1600$.

Bukit Tiwing also produced both inshore and pelagic species, including a wide variety of fish species after around $\mathrm{AD} 1600$, which shows a similar pattern to the Leang Buida upper layers. Although the Bukit Tiwing excavation produced no fishing tools and marine faunal remains are more limited at the site, possibly because of its location on a hill side, the high proportions of Lethrinids including Monotaxis sp., Lutjanids and Serranids indicate the use of angling.

When the analytical results from both Leang Buida and Bukit Tiwing are combined, it is apparent that basic fishing methods such as angling, netting and spearing were already practised at around $\mathrm{AD} 1000$, but that a wider variety of fishing methods and gear appeared after AD 1600. Lure fishing with shell-made lure shanks appear to be one of the new fishing techniques in the Talauds, as confirmed by the appearance of pelagic fish species in both sites after AD 1600. Capture of sea turtles was also practised after $\mathrm{AD} 1600$. 
In terms of shellfish exploitation, a greater variety of species were exploited at Leang Buida than Bukit Tiwing, though the status of Neritidae and Turbinidae as the main exploited families is similar at both sites. ${ }^{3}$ A similar pattern of shellfish use is also found at Leang Sarru on Salibabu Island, dating back to 35,000 years ago (Tanudirjo 2005; Ono et al. 2009), indicating that Turbinidae and Neritidae had been the most commonly exploited shells for over 30,000 years up to AD 1800 in the Talaud Islands. Other molluscs recovered in quantity from both Leang Sarru and Leang Buida include Trochidae, Chitonidae and Ellobiidae. On the other hand, some shellfish families such as Cypraenidae, Vasidae and Fissurellidae are common at Leang Buida but not Leang Sarru, and differences like these could be affected by the sites' location and surrounding coastal environment. Temporal changes in shell exploitation are not very clear at either site, although a larger number and variety of shellfish were exploited at Leang Buida after AD 1600.

Turning next to the exploitation of terrestrial resources, we note that our excavation at Leang Buida indicates the introduction and use of goats and pigs by AD 1000. Since no such domesticated animals were recorded at previous excavations of earlier sites in the Talaud Islands, the Leang Buida finds stand as the earliest evidence for the introduction of domesticated animals to the Talauds. In general, the major domesticated animals including pig, dog and chicken were introduced into ISEA and the Pacific after Neolithic times from around 1500-1000 BC. However, no such animal bones were recovered from the single site in the Talaud Islands with Neolithic occupation (Leang Tuwo Mane'e), and so the date for the earliest introduction of domesticated animals into the Talaud group is still unclear.

Bukit Tiwing produced dog bones as well as pig, goat and rat bones dated to after AD 1500. Dogs and rats are also identified in the Talaud faunal record after AD 1500, but possibly introduced to the islands earlier since goats and pigs were already in evidence by at least AD 1000 at Leang Buida. The number of identifications of pig far exceeds any other mammal at Bukit Tiwing, with at least 12 pigs accounted for at the site. Most of the pig mandibles reflect an age at death of less than two years, and it is highly likely that pigs were slaughtered for food. The rats are not yet identified to the family or species level, and it is uncertain whether they were exploited by humans as food or died naturally at the site. Overall, it appears that a greater variety of terrestrial animals appeared after AD 1500 and most of them were exploited by humans for food.

In terms of plant remains, both sites produced nut shells and stone artefacts identified as nut crackers. Canarium nut is nowadays a very popular and common food in the Sangihe-Talaud Islands and elsewhere in North Sulawesi. Our excavation in Leang Buida demonstrates the use of Canarium back to AD 1000, though it could have a longer history of human use and possibly cultivation in the region.

\section{Development of regional maritime networks}

When we consider archaeological evidence for the possible development of inter-island maritime networks, earthenware pottery and imported ceramics can be just as important as introduced fauna and botanical remains. In the Talaud Islands, located at the eastern margin of the Sulawesi Sea, most of the excavated trade ceramics are late Ming and Qing wares, and their numbers are limited. So far, the oldest possible ceramics in the Talaud Islands are two thick fragments of stoneware from the lowest layer of Leang Buida dating to around AD 1000. Although the origin and age of these stoneware fragments are as yet unknown, they appear different from Ming and Qing wares or indeed Thai and Vietnamese tradewares, and could be much older as indicated by the associated Carbon-14 dates.

3 To be sure, there were more Neritidae than Turbinidae at Leang Buida, but the Neritidae shells are generally small, and so it is clear that the Turbinidae were the more important food source. 
Bellwood (1976:266) reported that the top layer of Leang Tuwo Mane'e site produced a small number of Chinese wares dating back to the Tang or Song Dynasty, around 1000 years ago. Tanudirjo's re-excavation of the site also collected a blue-and-white porcelain sherd and a light green celadon sherd from the top layer, but they were too small to be identified. Although no Carbon-14 dates were obtained from this top layer, the dates obtained from Layer 2 (see footnote 1 above) include two dates on charcoal between approximately AD 1400 and 1700, and an older determination on Turbo shell, which is unreliable in view of the marine reservoir effect on dates from marine shell. Accordingly, Layer 1 could date to no earlier than the 15 th-18th centuries AD, and so it is unclear whether the Tang or Song ceramics reported by Bellwood had been imported to the Talaud Islands at around the time of their manufacture or much later as antique goods. Indeed, these ceramics might date to after the Song Dynasty, because there are no photographs, drawings or detailed descriptions of these excavated trade ceramics in Bellwood (1976).

The only tradewares identified from younger sites including Leang Arandangana (Tanudirjo 2001) and Bukit Tiwing are represented by late Ming to Qing sherds recovered from the upper layers. The numbers of these trade ceramics are much larger than older ceramic types, which might suggest that long-distance maritime trade networks were established at around the late 14th or 15th century in the Talaud Islands. However, Bellwood (1976:282) also collected some possible Tang and Yuan sherds as well as Rarangunusa-style potsherds as surface finds at Leang Timpalo on Sangir Island. We were also shown possible Song and Yuan trade ceramics by local antique dealers during our surveys of Sangir Island. According to them, these ceramics were illegally excavated or collected in the Sangihe Islands. Based on this information, the establishment of long-distance maritime trade networks to the Sangihe Islands possibly dates to around the 13th century.

Turning our review to the eastern coast of Borneo, we observe that the upper layers of the Madai caves, located about $30 \mathrm{~km}$ inland from the coast, produced sherds of Ming wares along with a few Thailand and Vietnamese tradewares (Bellwood 1988). Also, the old port site of Bukit Silam on Borneo's eastern coast yielded a large number of trade ceramics along with gold and glass ornaments. The excavated ceramics are mainly Ming wares, supplemented by a minority of Yuan wares, along with Thailand and Vietnamese tradewares (Aoyagi 1992). While no Carbon-14 determinations were obtained, the Bukit Silam site suggests that the eastern coast of Borneo was connected to long-distance maritime trade networks by around the late 13th or 14th century.

Beside the trade ceramics, earthenware pottery motifs and styles can be an indicator of local inter-island interaction. In the Talaud Islands, both Leang Buida and Bukit Tiwing produced Rarangunusa-style potteries after AD 1500, while Leang Buida produced possible prototype Rarangunusa pottery dated to around AD 1000. Leang Arandangana also produced Rarangunusa pottery, possibly after AD 1500 (Tanudirjo 2001). Across the wider area, Rarangunsa-style pottery was also excavated from the De Arce House site in southern Mindanao and possibly dated back to around the 15th century (Solheim et al. 1979:Figure 29b), while the Bungao rockshelter in south-western Mindanao also produced a potsherd with similar decoration (Spoehr 1973:164). Such evidence possibly indicates more frequent contacts between the Talaud Islands and Mindanao after AD 1400. The centre of origin of Rarangunusa pottery is uncertain, but the Talaud sites have produced the largest quantities of this type of pottery so far (Ono et al. 2013).

When we combine the ceramic and earthenware pottery evidence with the archaeological evidence for marine and terrestrial resource exploitation in the Talauds during AD 1000-1800, we concur with Bellwood (1976:283-284) that the Talaud Island inhabitants had connections with surrounding regions including the Sangihe Islands and Mindanao by at least AD 1000, succeeded by more frequent human movement and interactions after AD 1500. However, we can expand on Bellwood's proposed geographical range of connections by suggesting the inclusion of Tobi Island in Palau. Further, the Sangihe-Talaud Islands evidently fell in a gap 
between Spanish rule affecting the main Philippine islands (including Mindanao) and Islamic influences in the Sulu archipelago to the north, and the commercial and ideological contests in the Moluccas to the south (Watson Andaya 1992), without major change to the nature of Sangihe-Talaud Island society until the 19th century (Bellwood 1976; Henley 2005). It is true that the Portuguese, with their particular interest in Moluccan spices, were sufficiently aware of the Sangihe Islands to record the establishment of its four local chiefdoms by 1521 (Bellwood 1976:284), but the Dutch (who supplanted the Portuguese) did not recognise any particular commercial attractions in the Sangihe-Talaud Islands before establishing their initial presence there in the late 17th century (Ricklefs 2008:75). The Talaud Islands remained free from foreign intervention for many centuries, but this did not prevent their beneficial participation in exchange networks with neighbouring islands, notably the Philippines, as described here. This development of maritime inter-island networks promoted the development of fishing techniques employing a variety of gear and terrestrial resource use including the husbandry of domesticated animals in the Talaud Islands.

\section{Acknowledgements}

We would like to acknowledge Lembaga Ilmu Pengetahuan Indonesia, RISTEK and Pusat Arkeologi Nasional Indonesia for their administrative and moral support to our research. We are also greatly indebted to Dr Boony Tooy, the head of Balai Arkeologi Manado, for his kind support and assistance. The research and analysis were funded to Ono by the Japan Society of Promotion for Science (JSPS) 2003-2005, and also 2011-2012.

\section{Author biographies}

Rintaro Ono School of Marine Science and Technology, Tokai University, Japan; and Department of Archaeology and Natural History, School of Culture, History and Language, College of Asia and the Pacific, The Australian National University, Canberra, Australia

Sriwigati Manado Archaeology Office, Manado, North Sulawesi, Indonesia

Joko Siswanto Manado Archaeology Office, Manado, North Sulawesi, Indonesia

\section{References}

Aoyagi, Y. 1992. Asian trade ceramics in the Philippines: Ninth to Sixteenth Centuries. Journal of Sophia Asian Studies 10:144-176.

Bellina, B. 2003. Beads, social change and interaction between India and South-east Asia. Antiquity 77(296):285-297. doi.org/10.1017/S0003598X00092279 (accessed 5 June 2018).

Bellwood, P. 1976. Archaeological research in Minahasa and the Talaud Islands, Northeastern Indonesia. Asian Perspectives 19(2):240-288.

Bellwood, P. 1980. The Buidane culture of the Talaud Islands, north-eastern Indonesia. Bulletin of The Indo-Pacific Prehistory Association 2:69-127.

Bellwood, P. (ed.). 1988. Archaeological Research in South-Eastern Sabah. Sabah Museum Monograph 2. Kota Kinabalu: Sabah Museum.

Bellwood, P. 2017. First Islanders: Prehistory and Human Migration in Island Southeast Asia. Oxford: Wiley Blackwell. doi.org/10.1002/9781119251583 (accessed 5 June 2018).

\section{terra australis 48}


Bronk Ramsey, C. 2013. OxCal 4.2 manual. c14.arch.ox.ac.uk/oxcal/OxCal.html (accessed 27 October 2018).

Bulbeck, D. 2010. Uneven development in Southwest Sulawesi, Indonesia during the Early Metal Phase. In B. Bellina, E.A. Bacus, T.O. Pryce and J.W. Christie (eds), 50 Years of Archaeology in Southeast Asia: Essays in Honour of Ian Glover, pp. 153-169. Bangkok: River Books.

Calo, A., B. Prasetyo, P. Bellwood, J.W. Lankton, B. Gratuze, T.O. Pryce, A. Reinecke, V. Leusch, H. Schenk, R. Wood, R.A. Bawono, I.D.K. Gede, N.L.K.C. Yuliati, J. Fenner, C. Reepmeyer, C. Castillo and A.K. Carter. 2015. Sembiran and Pacung on the north coast of Bali: a strategic crossroads for early transAsiatic exchange. Antiquity 89:378-396. doi.org/10.15184/aqy.2014.45 (accessed 5 June 2018).

Cameron, J. 2005. Spindle whorls. In C.F.W. Higham (ed.), The Origins of the Civilization of Angkor: The Excavation of Ban Lum Khao, pp. 211-216. Bangkok: Fine Arts Department.

Cameron, J. 2011. The spinning tools. In C.F.W. Higham and A. Kijngam (eds), The Origins of the Civilizations of Angkor, Volume Five: The Excavation of Ban Non Wat Part III. The Bronze Age, pp. 492-500. Bangkok: Fine Arts Department.

Cameron, J. 2013. The spinning tools from Sunget, Anaro and Savidug. In P. Bellwood and E. Dizon (eds), 4000 Years of Migration and Cultural Exchange: The Archaeology of the Batanes Islands, Northern Philippines, pp. 115-121. Terra Australis 40. Canberra: ANU E Press.

Cameron, J. and A.S.B. Mijares. 2006. Report on an analysis of spindle whorl from Callao Cave, Peńablanca, Northern Luzon Philippines. Hukay 9:5-13.

Dussubieux, L. and B. Gratuze. 2010. Glass in Southeast Asia. In B. Bellina, E.A. Bacus, T.O. Pryce and J.W. Christie (eds), 50 Years of Archaeology in Southeast Asia: Essays in Honour of Ian Glover, pp. 246259. Bangkok: River Books.

Dye, T. 1983. Fish and fishing on Niuatoputapu, Tonga. Oceania 53(3):242-271. doi.org/10.1002/ j.1834-4461.1983.tb01983.x (accessed 5 June 2018).

Francis, P. 2002. Asia’s Maritime Bead Trade: 300 B.C. to the Present. Honolulu: University of Hawai'i Press.

Goto, A. 1986. Prehistoric Ecology and Economy of Fishing in Hawaii: An Ethnoarchaeological Approach. Unpublished PhD thesis, Department of Anthropology, University of Hawai'i, Manoa.

Goto, A. 1990. Prehistoric Hawaiian fishing lore: An integrated approach. Man and Culture in Oceania 6:1-34

Henley, D. 2005. Fertility, Food and Fever: Population, Economy and Environment in North and Central Sulawesi, 1600-1930. Leiden: KITLV Press.

Hung, H.-c. and P. Bellwood. 2010. Movement of raw materials and manufactured goods across the South China Sea after 500 BCE: From Taiwan to Thailand, and back. In B. Bellina, E.A. Bacus, T.O. Pryce and J.W. Christie (eds), 50 Years of Archaeology in Southeast Asia: Essays in Honour of Ian Glover, pp. 235-245. Bangkok: River Books.

Hung, H.-c., M.T. Carson, P. Bellwood, F.Z. Campos, P.J. Piper, E. Dizon, M.J.L.A. Bolunia, M. Oxenham and Z. Chi. 2011. The first settlement of Remote Oceania: The Philippines to the Marianas. Antiquity 85(329):909-926. doi.org/10.1017/S0003598X00068393 (accessed 5 June 2018).

Hung, H.-c., K.D. Nguyen, P. Bellwood and M.T. Carson. 2013. Coastal connectivity: Long-term trading networks across the South China Sea. The Journal of Island and Coastal Archaeology 8(3):384-404. doi.org/10.1080/15564894.2013.781085 (accessed 5 June 2018).

Intoh, M. and R. Ono. 2006. Reconnaissance archaeological research on Tobi Island, Hatohobei State, Palau. People and Culture in Oceania 22:53-82. 
Kirch, P.V. 1997. The Lapita Peoples: Ancestors of the Oceanic World. Oxford: Blackwell.

Kirch, P.V. and W.R. Dickinson. 1976. Ethno-archaeological investigations in Futuna and Uvea (Western Polynesia): A preliminary report. The Journal of the Polynesian Society 85(1):27-69.

Kirch, P.V. and T.S. Dye. 1979. Ethno-archaeology and the development of Polynesian fishing strategies. The Journal of the Polynesian Society 88:53-76.

Li, K.C. 1997. Change and Stability in the Dietary System of a Prehistoric Coastal Population in Southern Taiwan. Unpublished PhD thesis, School of Anthropology, Arizona State University, Tucson.

Li, K.C. 2002. Prehistoric marine fishing adaptation in southern Taiwan. Journal of East Asian Archaeology 3(1-2):47-74.

Masse, W.B. 1986. A millennium of fishing in the Palau Islands, Micronesia. In A. Anderson (ed.), Traditional Fishing in the Pacific: Ethnographic and Archaeological Papers from the 15th Pacific Science Congress, pp. 85-117. Pacific Anthropological Records 37. Honolulu: Bernice P. Bishop Museum.

Masse, W.B. 1989. The Archaeology and Ecology of Fishing in the Belau Islands, Micronesia. Unpublished PhD thesis, Department of Anthropology, Southern Illinois University, Carbondale.

Nakamura, T. 2003. Calibration of radiocarbon ages for marine samples. Proceedings of the 16th Symposium on Researches Using the Tandetron AMS System, Nagoya University.

O'Connor, S., R. Ono and C. Clarkson. 2011. Pelagic Fishing at 42,000 Years Before the Present and the Maritime Skills of Modern Humans. Science 334(6059):1117-1121. doi.org/10.1126/science. 1207703 (accessed 5 June 2018).

Oliver, D.L. 1989. Oceania: The Native Cultures of Australia and the Pacific Islands. Honolulu: University of Hawai'i Press.

Ono, R. 2004. An archaeological and ethno-archaeological Research on Settlement and Subsistence Patterns at Sangihe-Talaud Islands, North Sulawesi Province. Quarterly report submitted to Lembaga Ilmu Pengetahuan Indonesia, Jakarta.

Ono, R. 2010. Ethno-archaeology and early Austronesian fishing strategies in near-shore environments. The Journal of the Polynesian Society 119(3):269-314.

Ono, R. 2011. Marine Exploitation and Fishing Strategies in Celebes Sea: Area Studies in Maritime Southeast Asia. Kyoto: Kyoto University Press (in Japanese).

Ono, R., N. Nakajima, H. Nishizawa, S. Oda and S. Soegondho. 2015. Maritime migration and lithic assemblage on the Talaud Islands in northern Wallacea during the Late Pleistocene to the early Holocene. In Y. Kaifu, M. Izuho, T. Goebel, H. Sato and A. Ono (eds), Emergence and Diversity of Modern Human Behavior in Paleolithic Asia, pp. 201-213. College Station: Texas A\&M University Press.

Ono, R. and S. Soegondho. 2004. A short report for the re-excavation at Leang Sarru site, Talaud Islands. Jejak-Jejak Arkeologi 4:37-50.

Ono, R., S. Soegondho and J. Siswanto. 2013. Possible development of regional maritime networks during the 16th to 19th centuries: An excavation report of the Bukit Tiwing site in the Talaud Islands, eastern Indonesia. People and Culture in Oceania 29:1-33.

Ono, R., S. Soegondho and M. Yoneda. 2009. Changing marine exploitation during Late Pleistocene in Northern Wallacea: Shell remains from Leang Sarru Rockshelter in Talaud Islands. Asian Perspectives 48(2):318-341. doi.org/10.1353/asi.2009.0002 (accessed 5 June 2018). 
Piper, P., N. Amano Jr., S. H.-Y. Yang and T. O'Connor. 2013. The terrestrial vertebrate remains. In P. Bellwood and E. Dizon (eds), 4000 Years of Migration and Cultural Exchange: The Archaeology of the Batanes Islands, Northern Philippines, pp. 169-200. Terra Australis 40. Canberra: ANU E Press. doi.org/10.22459/TA40.12.2013.10 (accessed 5 June 2018).

Ricklefs, M. 2008. A History of Modern Indonesia since c. 1200. New York: Palgrave MacMillan.

Riley, J. 2002. Mammals on the Sangihe and Talaud Islands, Indonesia, and the impact of hunting and habitat loss. Oryx 36(3):288-296. doi.org/10.1017/S0030605302000510.

Rolett, B.V. 1989. Hanamiai: Changing Subsistence and Ecology in the Prehistory of Tahuata, Marquesas Islands, French Polynesia. Unpublished PhD thesis, Department of Anthropology, Yale University, New Haven.

Samper Carro, S.C., S. O'Connor, J. Louys, S. Hawkins and M. Mahirta. 2016. Human maritime subsistence strategies in the Lesser Sunda Islands during the terminal Pleistocene-early Holocene: New evidence from Alor, Indonesia. Quaternary International 416:64-79. doi.org/10.1016/j.quaint. 2015.07.068 (accessed 5 June 2018).

Soegondho, S. 1996. Penelitian Lepurbakalaan di Desa Aboru, Kacamatan Pulau Haruku, Maluku Utara. Unpublished report. Ambon: Proyek Penelitian Purbakala Maluku.

Solheim, W.G. II. 2006. Archaeology and Culture in Southeast Asia: Unraveling the Nusantao. Quezon City: The University of the Philippines Press.

Solheim, W.G. II, A.M. Legaspi and J.S. Neri. 1979. Archaeological Survey in Southern Mindanao. Monograph 8. Manila: National Museum of the Philippines and the University of Hawai'i.

Spoehr, A. 1973. Zamboanga and Sulu: An Archaeological Approach to Ethnic Diversity. Ethnology Monographs No. 1. Pittsburgh: University of Pittsburgh.

Szabó, K. 2010. Shell artefacts and shell-working within the Lapita Cultural Complex. Journal of Pacific Archaeology 1(2):115-127.

Tanudirjo, D.A. 2001. Islands in Between: Prehistory of the Northeastern Indonesian Archipelago. Unpublished PhD thesis, School of Archaeology and Anthropology, The Australian National University, Canberra.

Tanudirjo, D.A. 2005. Long-continuous or short-occasional occupation? The human use of Leang Sarru rockshelter in the Talaud Islands, northeastern Indonesia. Bulletin of The Indo-Pacific Prehistory Association 25(3):15-19.

Watson Andaya, B. 1992. Religious developments in Southeast Asia c. 1500-1800. In N. Tarling (ed.), The Cambridge History of Southeast Asia: Volume 1, From Early Times to c. 1800, pp. 508-571. Cambridge: Cambridge University Press.

Yamagata, M., C.H. Bui and K.D. Nguyen (eds). 2013. The Excavation of Hoa Diem in Central Vietnam. Showa Women's University Institute of International Culture Bulletin 17. Setagaya, Tokyo: Showa Women's University Institute of International Culture.

Yoneda, M., R. Suzuki, Y. Shibata, M. Morita, T. Sukegawa, N. Shigehara and T. Akazawa. 2004. Isotopic evidence of inland-water fishing by a Jomon population excavated from the Boji site, Nagano, Japan. Journal of Archaeological Science 31(1):97-107. doi.org/10.1016/S0305-4403(03)00103-1 (accessed 5 June 2018). 
This text is taken from The Archaeology of Sulawesi: Current Research on the Pleistocene to the Historic Period, edited by Sue O'Connor, David Bulbeck and Juliet Meyer, published 2018 by ANU Press, The Australian National University, Canberra, Australia.

doi.org/10.22459/TA48.11.2018.15 